\title{
VITAL
}

VOICES

Issues That Impact Virginia Adults Age 45 and Older, December 2021

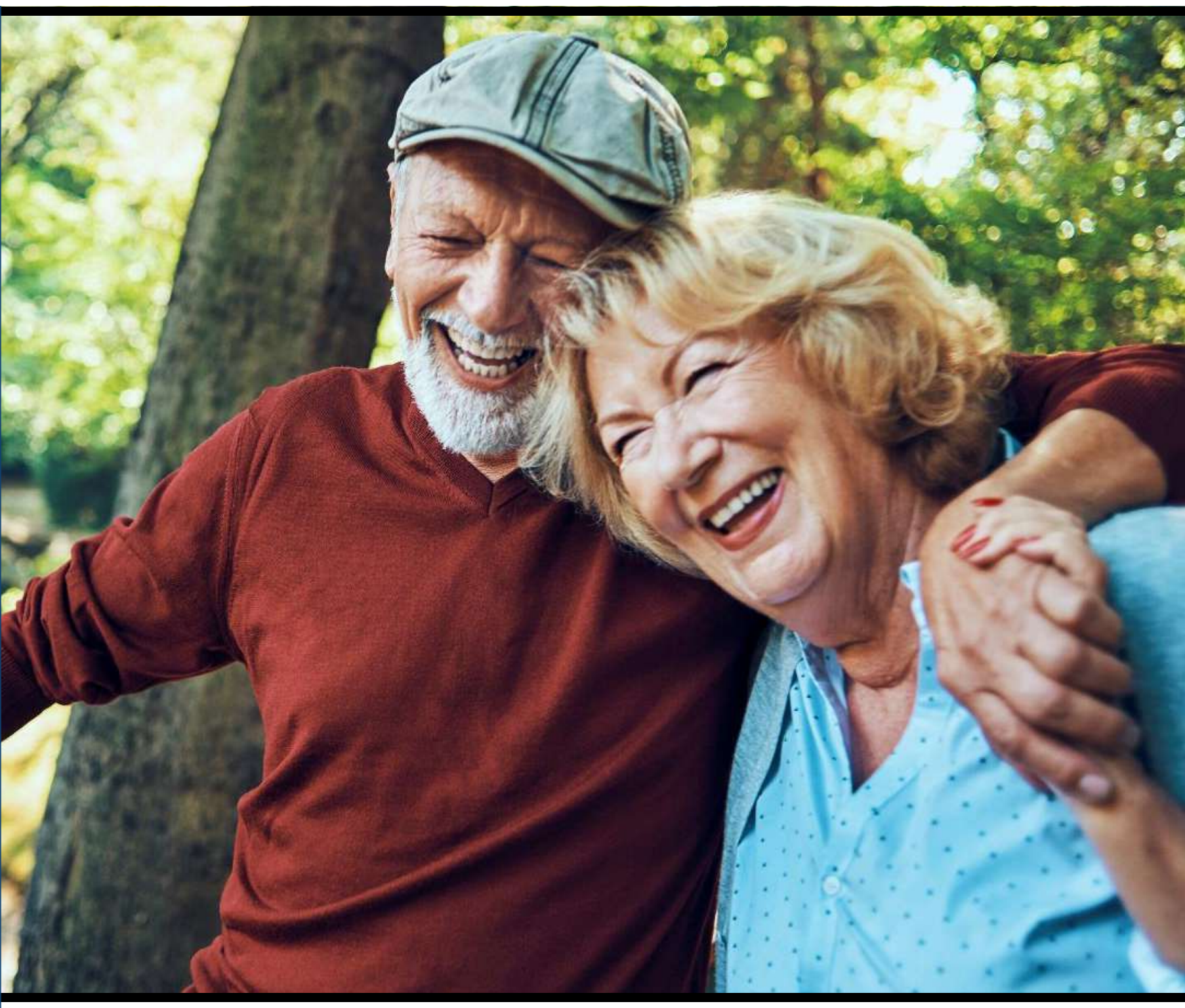




\section{TABLE OF CONTENTS}

Introduction to Vital Voices Surveys

Health Questions

Wealth Questions

Self Questions

Methodology

About AARP

Contact
3

4

14

20

27

29

30

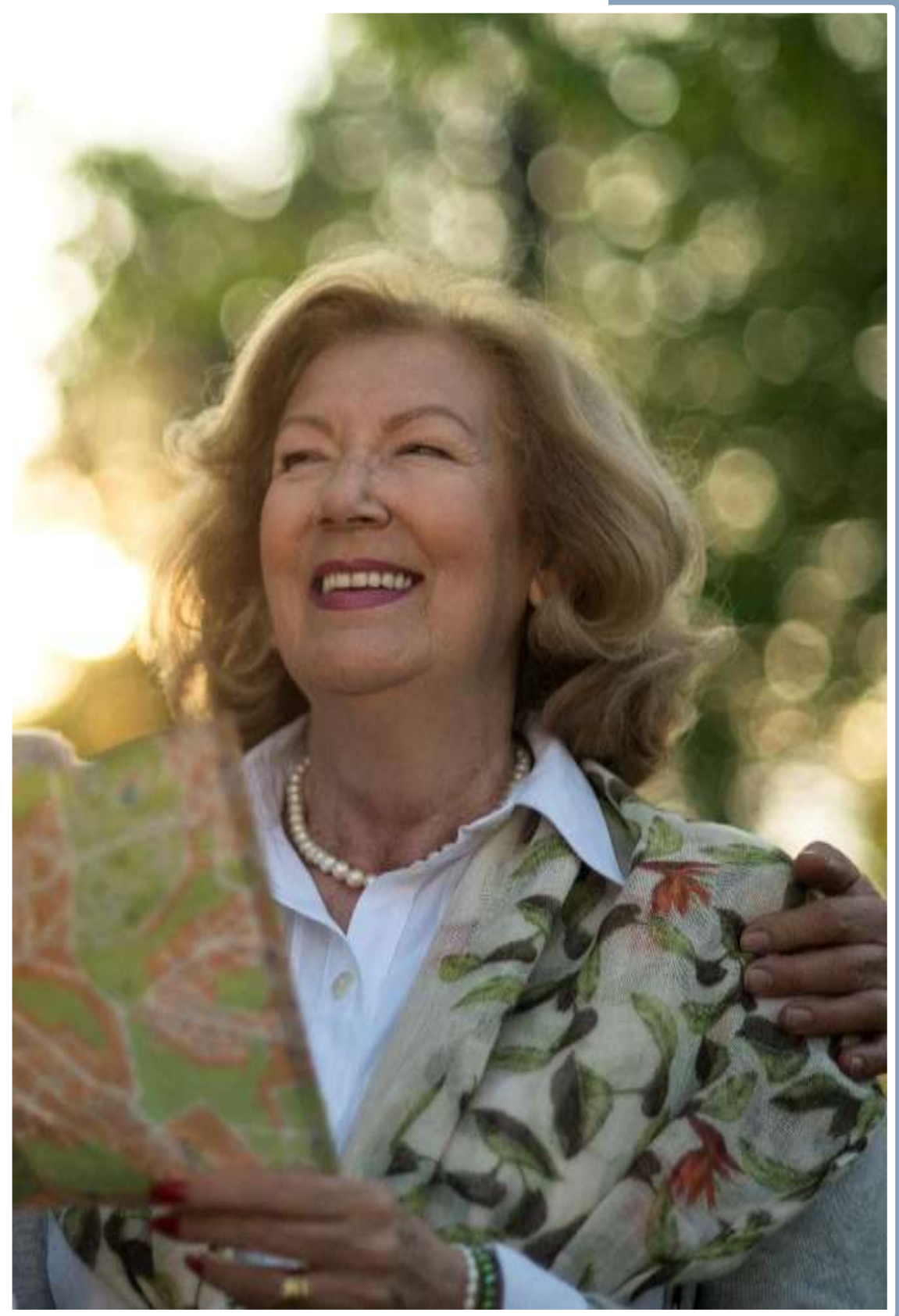




\section{INTRODUCTION}

There are currently about 117 million Americans who are 50 and older; this number will grow to 157 million by 2050 . The 50 and older population is and will continue to be an essential contributor to American society. Understanding the needs and opinions of older Americans is critical to ensuring they live longer and healthier lives.

Vital Voices is a new and exciting program of research undertaken by AARP. Through this research program, we are launching a new initiative that will deliver critical, current, and state-specific data to 53 states on a rolling three-year schedule between 2019 and 2021. We are making this data available to the public to assist with the development of programs, products, and policies for older adults. This data will allow those in leadership positions to:

- Predict the need for a specific program or interest in a particular issue.

- Enhance program and product innovation and development.

- Track issues and attitudes over time to assess shifts in public opinion.

- Take action on critical advocacy issues.

Never before has AARP launched a research program of this size and with this much promise. We give it to you, hoping that it will significantly impact the work you do.

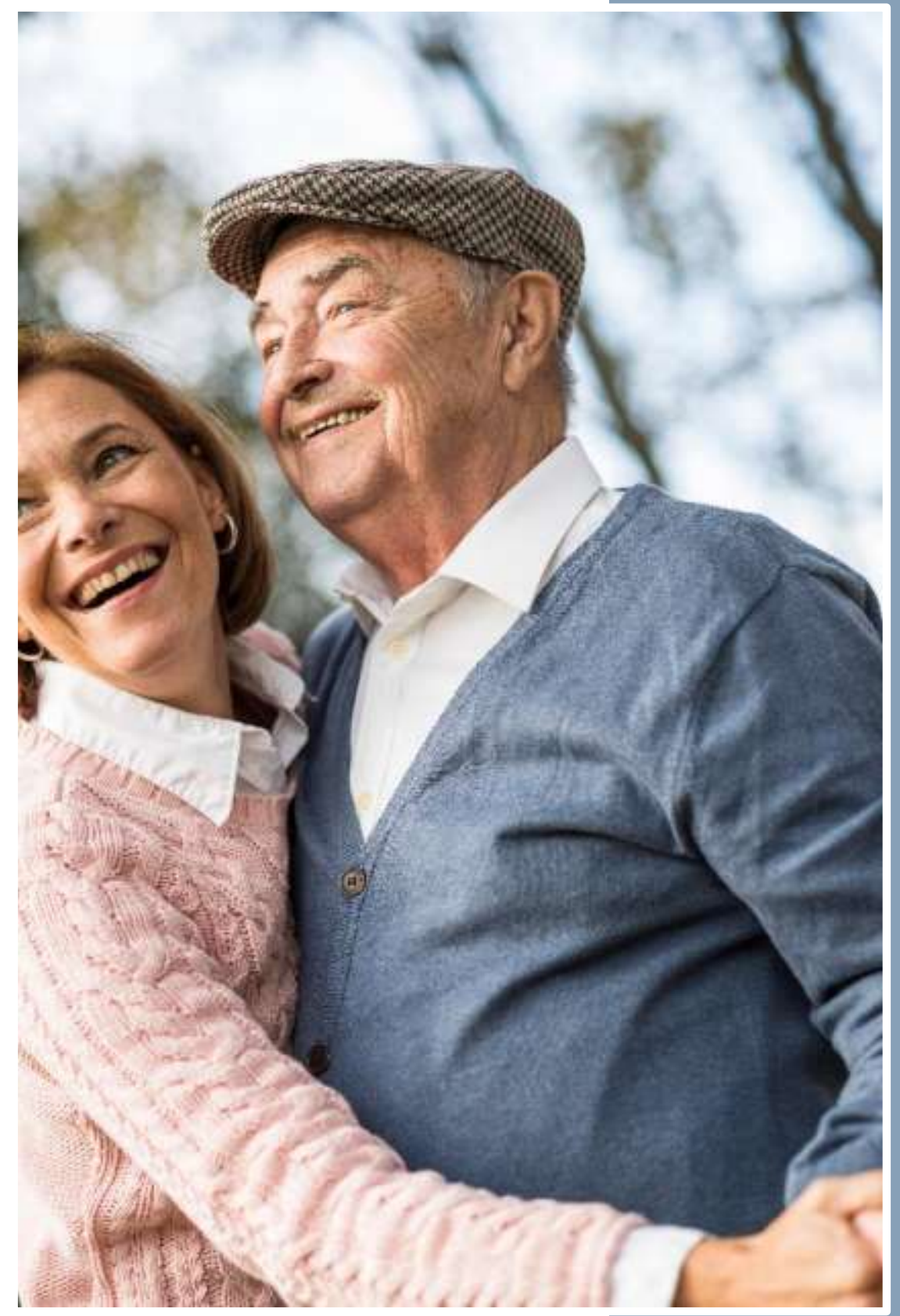




\section{Survey Results for}

Virginia-

\section{Health Questions}

Issues That Impact Virginia Adults Age 45 and Older

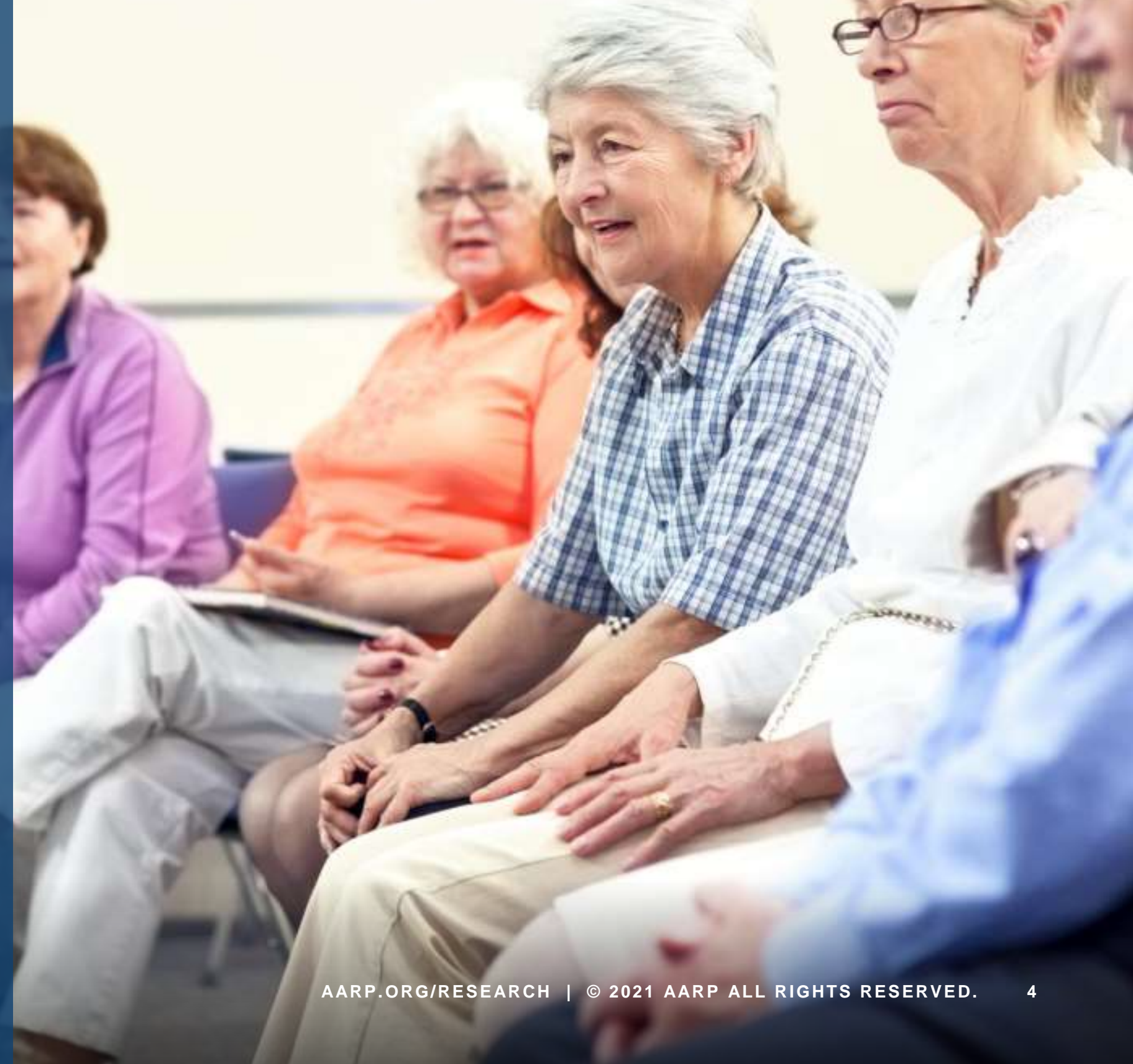




\section{ISSUES OF IMPORTANCE}

Virginia residents age 45+ think many healthcare issues are important, with staying mentally sharp topping the list.

\section{Important Healthcare Issues}

Staying mentally sharp

Having adequate health insurance coverage

Having Medicare benefits available to you in the future

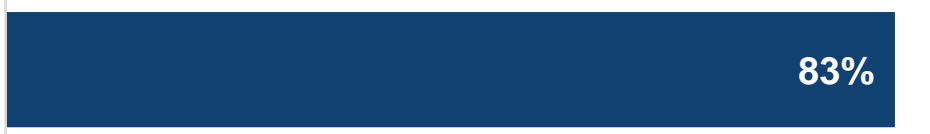

Paying for health care expenses

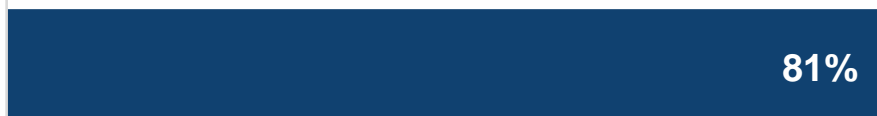

Paying for prescription drugs

$73 \%$ 


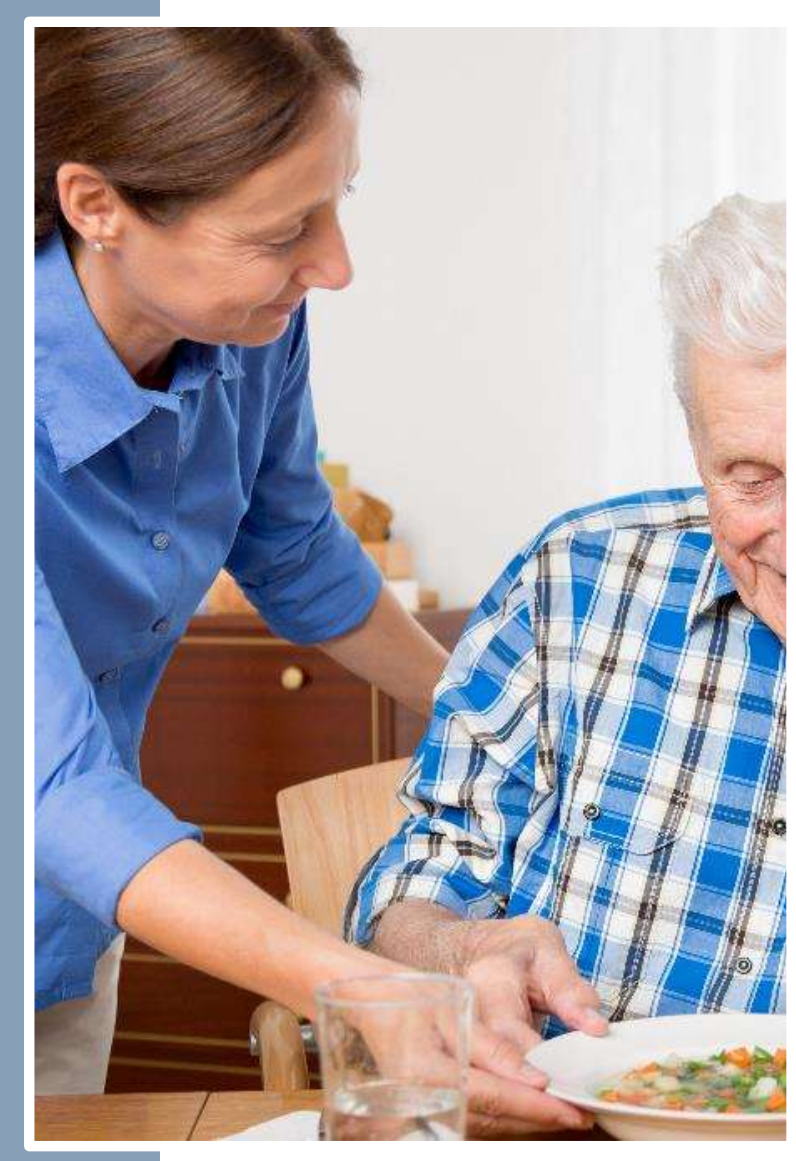

CAREGIVING

Over one-quarter (30\%) of Virginia residents age $45+$ are currently providing unpaid help to an adult relative or friend.

\section{Percent Providing Unpaid Adult Care}

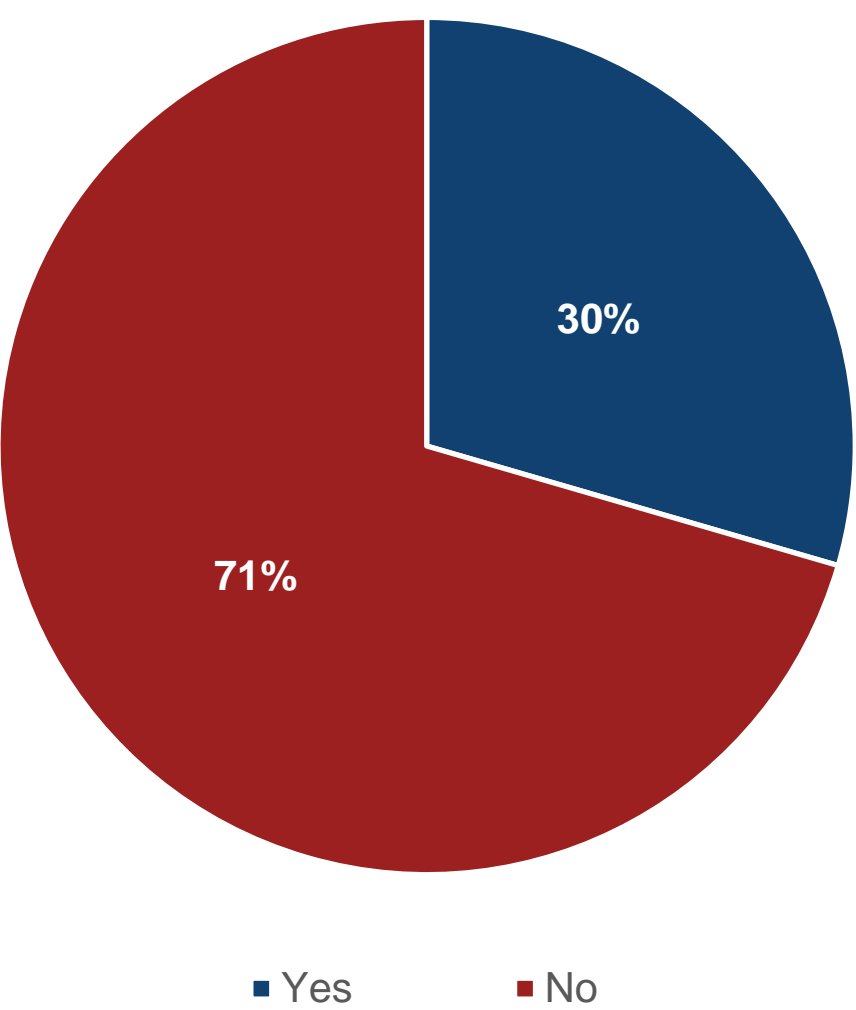




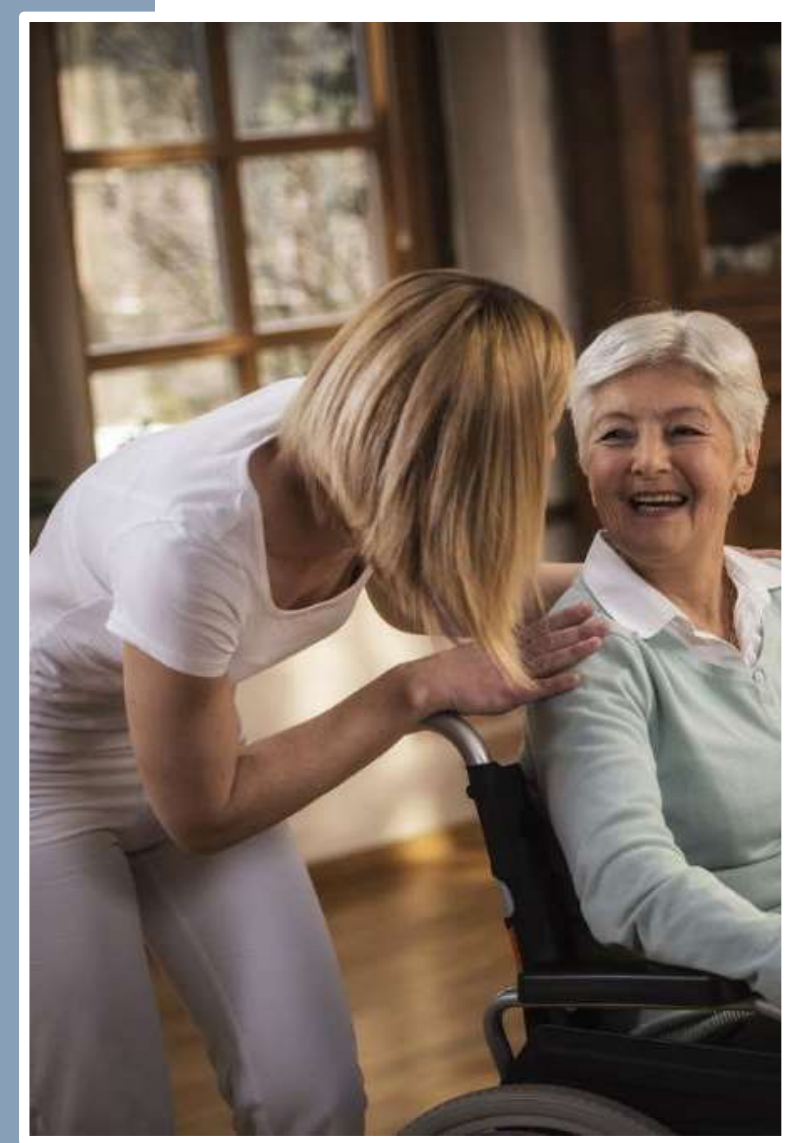

CARE1_A. Have you ever provided this type of unpaid help in the past? $(n=267)$

\section{CAREGIVING}

Almost half (47\%) of Virginia residents age $45+$ who are not currently unpaid caregivers have provided this type of care in the past.

\section{Percent Providing Unpaid Adult Care in The Past}

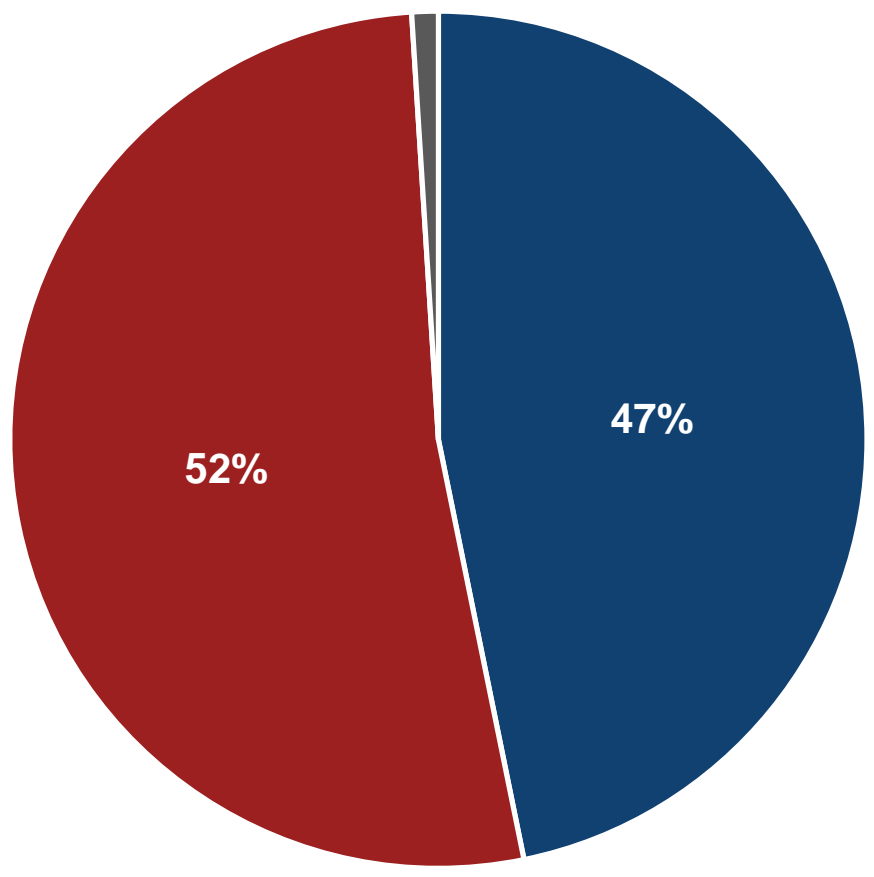

- Yes - No - Don't know 


\section{CAREGIVING}

\section{Virginia caregivers age 45+ face many difficulties, with half (53\%) feeling stressed}

emotionally due to their caregiving responsibilities.

\section{Caregiving Difficulties}

Feel stressed emotionally due to your caregiving
responsibilities

Find it difficult to exercise regularly

Find it difficult to get enough rest

Find it difficult to take care of your household responsibilities

Experience problems with your health

Feel stressed in trying to balance your job and family

Find it difficult to maintain a healthy diet

Feel strained financially due to your caregiving responsibilities

Find it difficult to make time to visit your doctor

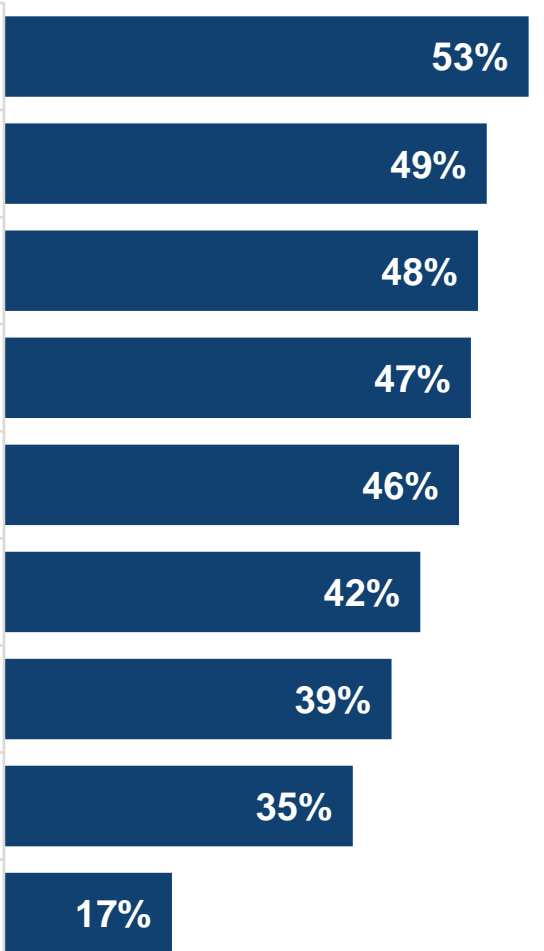




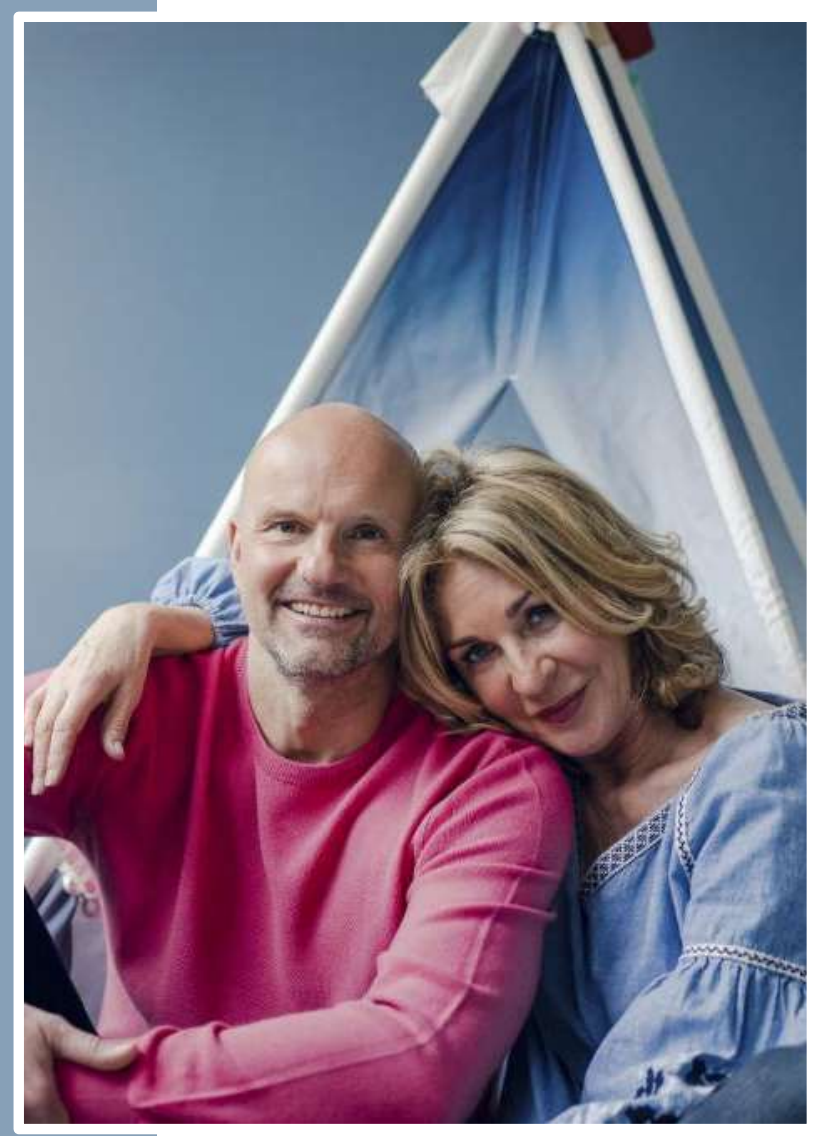

ISO8. How is your overall health at this point in time? $(n=379)$

\section{HEALTH}

About half (49\%) of Virginia residents age $45+$ reported that their health is excellent or very good.

Overall Health Status

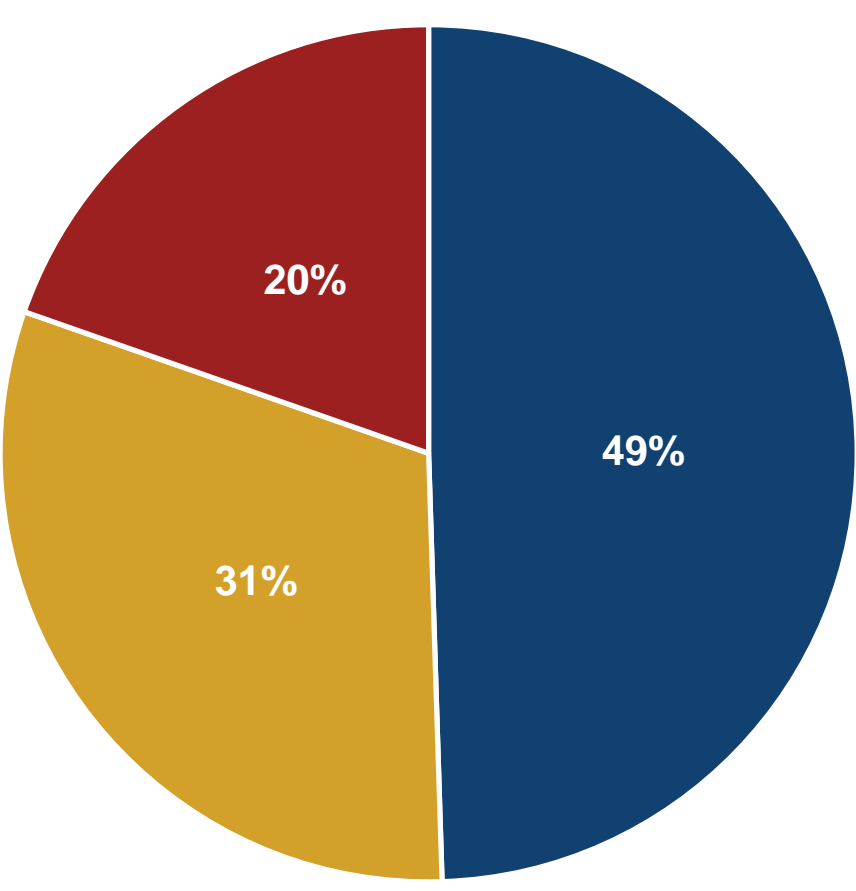

- Excellent/ very good

- Fair/ poor 


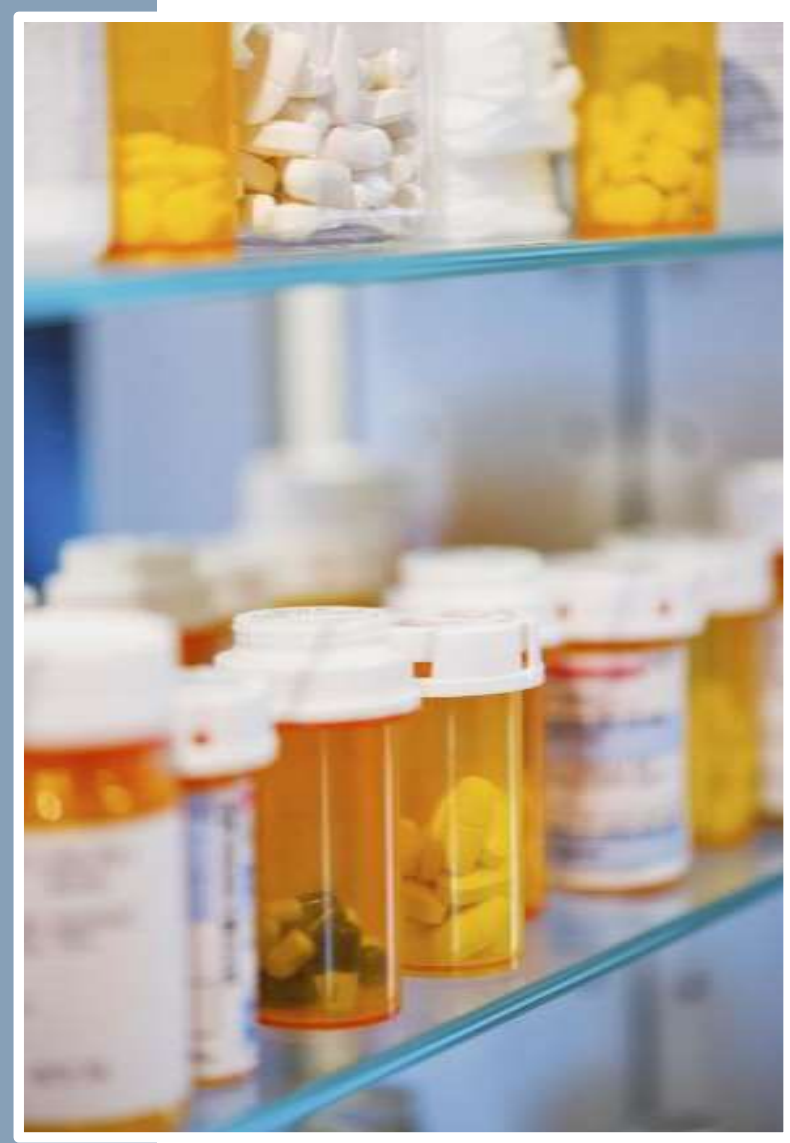

PER2. Approximately how many different prescription medications do you take on a regular basis such as daily, weekly, or monthly? $(n=379)$ Chart does not equal onehundred percent due to removal of small cells; see annotation for all categories

\section{PRESCRIPTION DRUGS}

Three-quarters (77\%) of Virginia residents age $45+$ take at least one prescription medication on a regular basis.

\section{Number of Prescription Medications Taken Regularly}

None

$22 \%$

$15 \%$

2 to 3

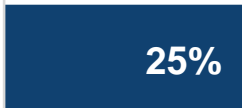

4 to 5

$19 \%$

6 or more

$18 \%$ 


\section{PRESCRIPTION DRUGS}

Seventeen percent (17\%) of Virginia residents age $45+$ spend $\$ 100$ or more out-ofpocket each month for prescription drugs.

\section{Spending on Prescription Drugs}

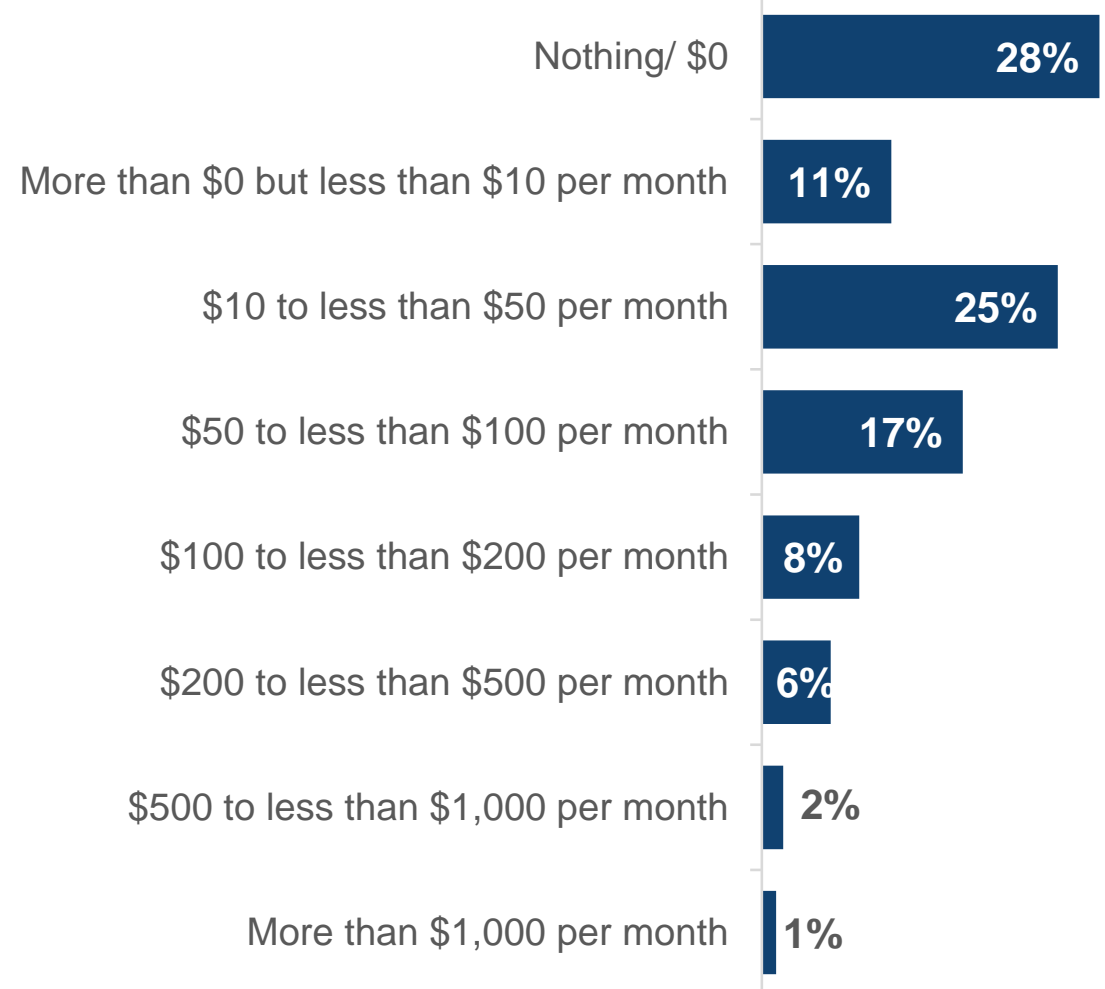

PER3. In the past 12 months, approximately how much have you spent out of your own pocket for prescription drugs? ( $\mathrm{n}=379$ )

Chart does not equal one-hundred percent due to removal of small cells; see annotation for all categories 


\section{PRESCRIPTION DRUGS}

\section{Virginia residents age 45+ have faced a variety of difficult decisions when buying}

prescription medications.

\section{Actions Taken in the Past 12 Months} Decided not to fill a prescription because of the cost of the
drug

Delayed getting a prescription filled because of the cost

Taken less medicine than prescribed to make it last longer

Cut back on such items as food, fuel, or electricity to afford prescription drugs

Decided not to fill a prescription to use the money for a living expense

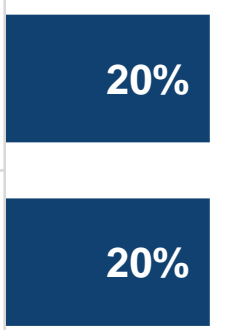

$18 \%$

$15 \%$

$13 \%$ 


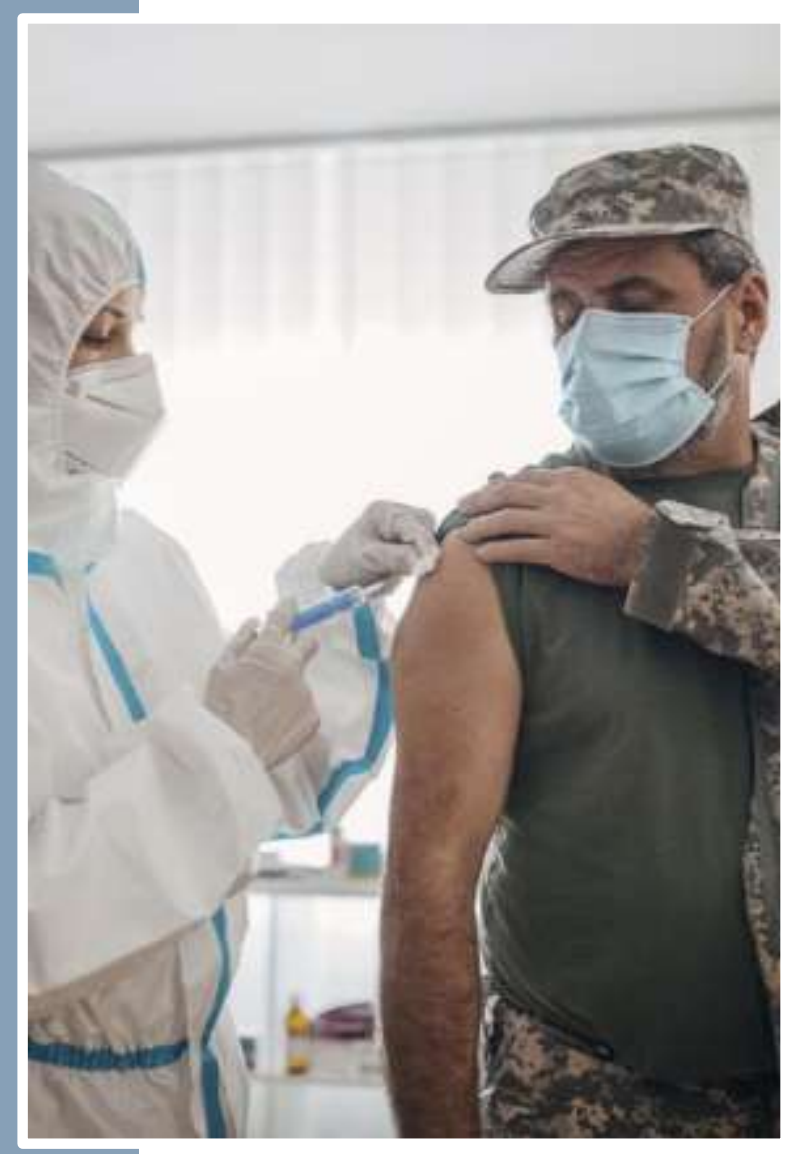

CVD-11. Have you gotten or do you plan to get the COVID-19 vaccine? $(n=379)$

\section{COVID-19}

As of December 2021, a majority (83\%) of Virginia residents age 45+ have already gotten the COVID-19 vaccine (or plan to get it).

\section{COVID-19 Vaccination Status}

(as of December 2021)

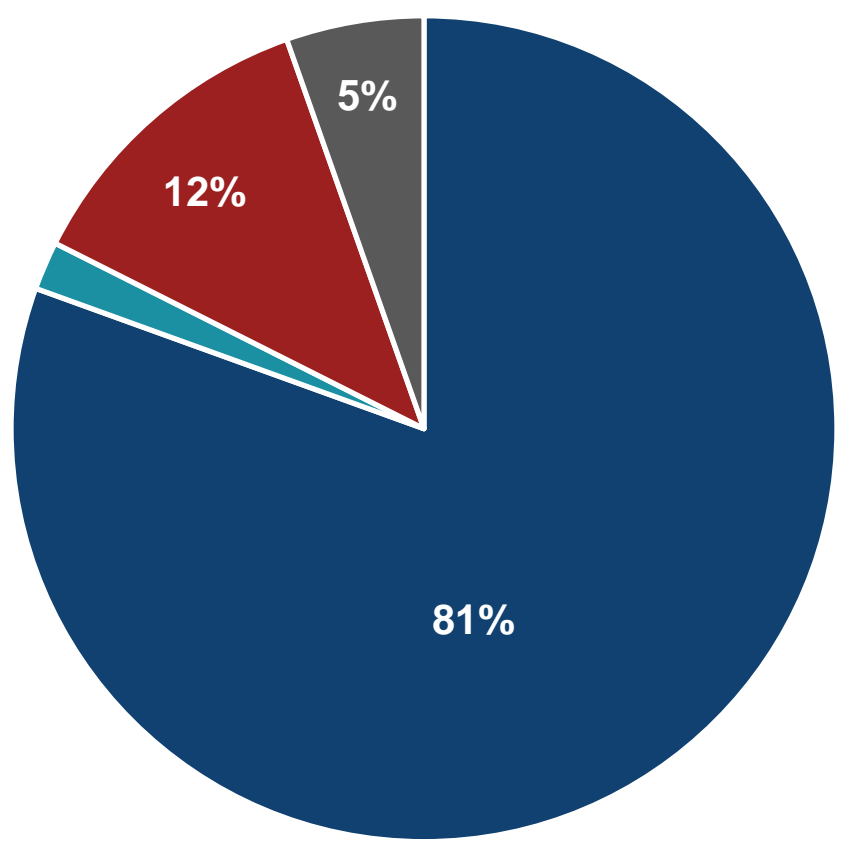

- Yes (already got) - Yes (plan to) - No - Don't know/ refused 


\section{Survey Results for Virginia- Wealth Questions}

Issues That Impact Virginia Adults Age 45 and Older

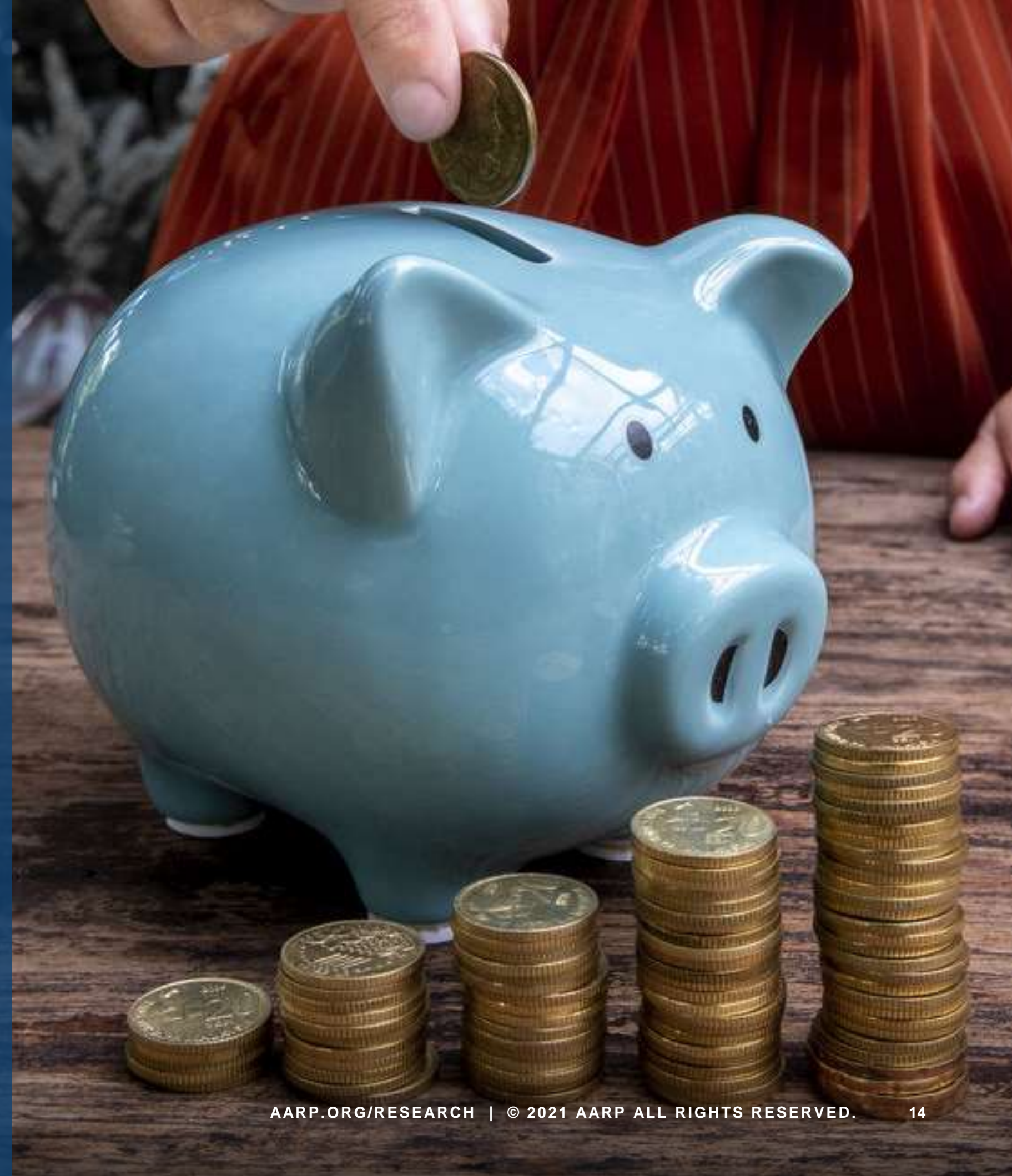




\section{ISSUES OF IMPORTANCE}

\section{Virginia residents age 45+ find many economic issues important, particularly those related to retirement and Social Security benefits.}

\section{Important Economic Issues}

Having enough income or savings to retire

Having adequate Social Security benefits

Protecting yourself against consumer fraud

Protecting yourself against unfair financial practices

$$
\text { Having online security }
$$

Being able to stop working for pay at the age you want

Protection from age discrimination

Having good employment opportunities in your community

Maintaining relevant job skills and experience

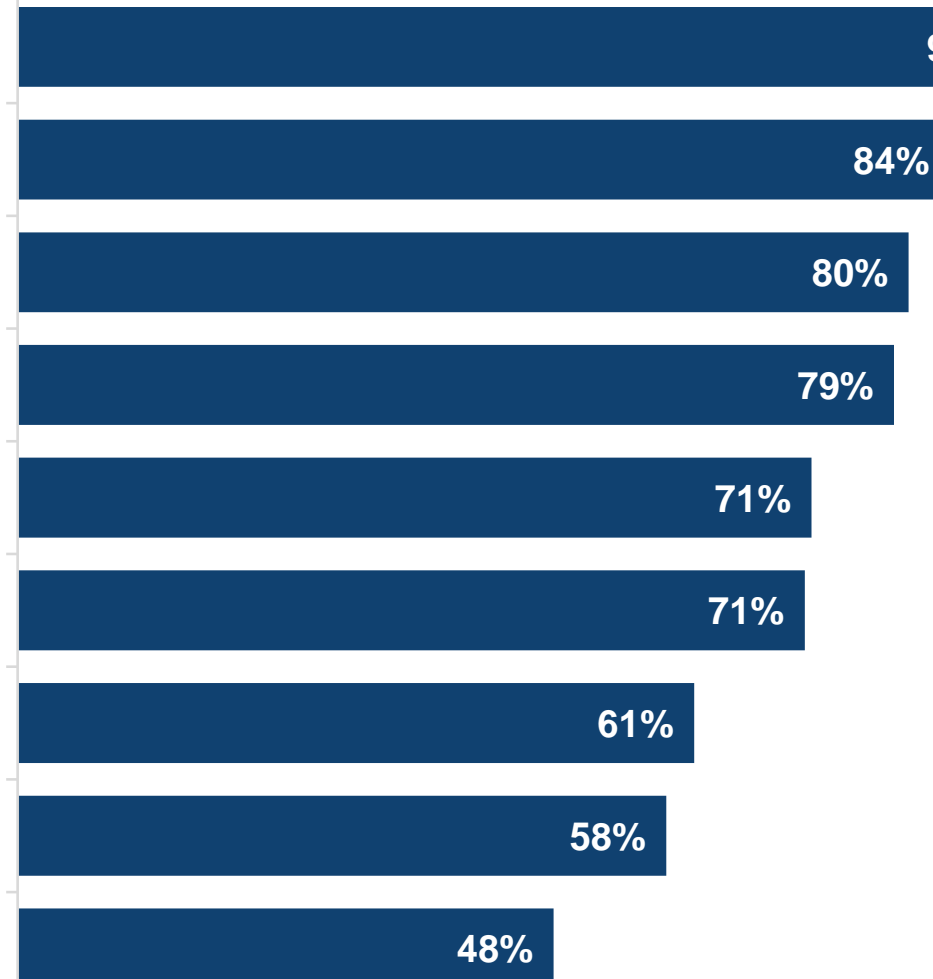




\section{RETIREMENT ISSUES}

Nearly half $(47 \%)$ of Virginia residents age $45+$ are extremely or very concerned about having enough income or savings to retire.

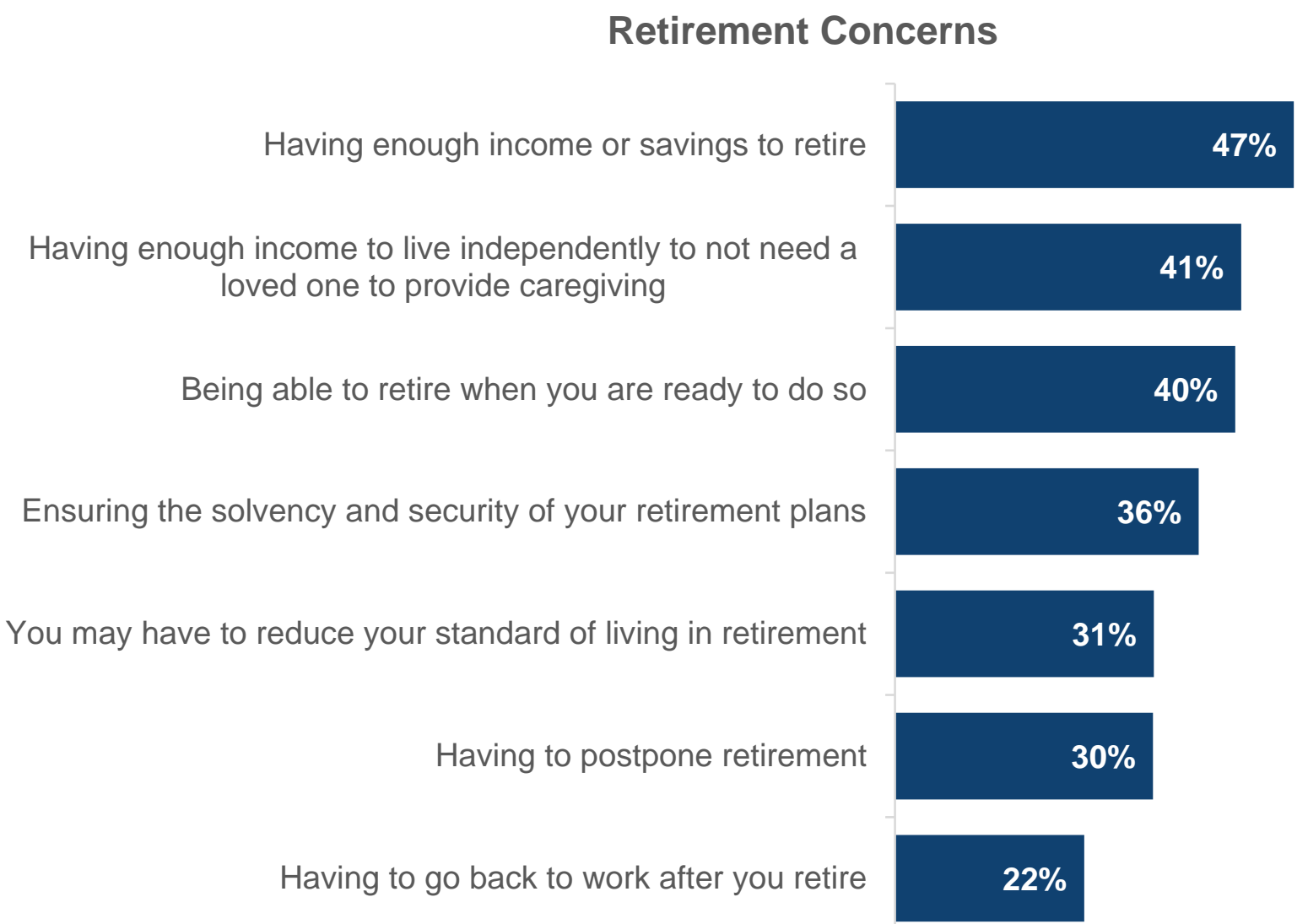

RET1. How concerned are you about the following? (Percent 'extremely concerned' or 'very concerned') ( $n=v a r i e s)$ 


\section{FRAUD}

Virginia residents age 45+ have many concerns about fraud, including having their identity stolen (54\%) and having hackers access their identifying information (53\%).

\section{Concern About Scams and Fraud}

Having your identity stolen by someone who uses your name and other identifying information to open new credit accounts

Having hackers get access to your identifying information from companies that you have done business with
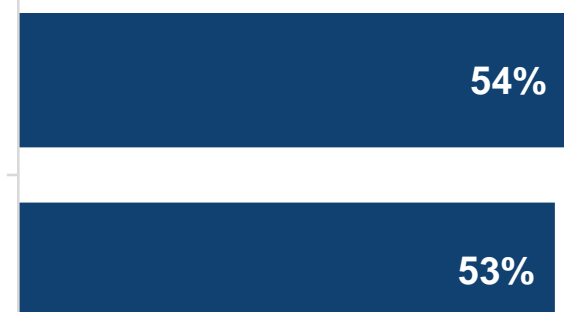

Losing money due to unfair or fraudulent financial practices

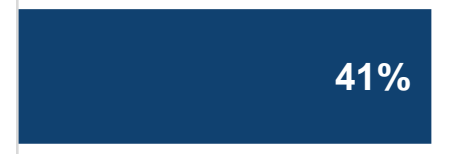

Becoming the target or victim of an internet scam or fraud

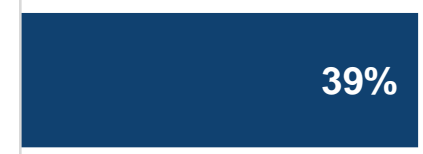

Becoming the target or victim of a phone scam or fraud over the phone 


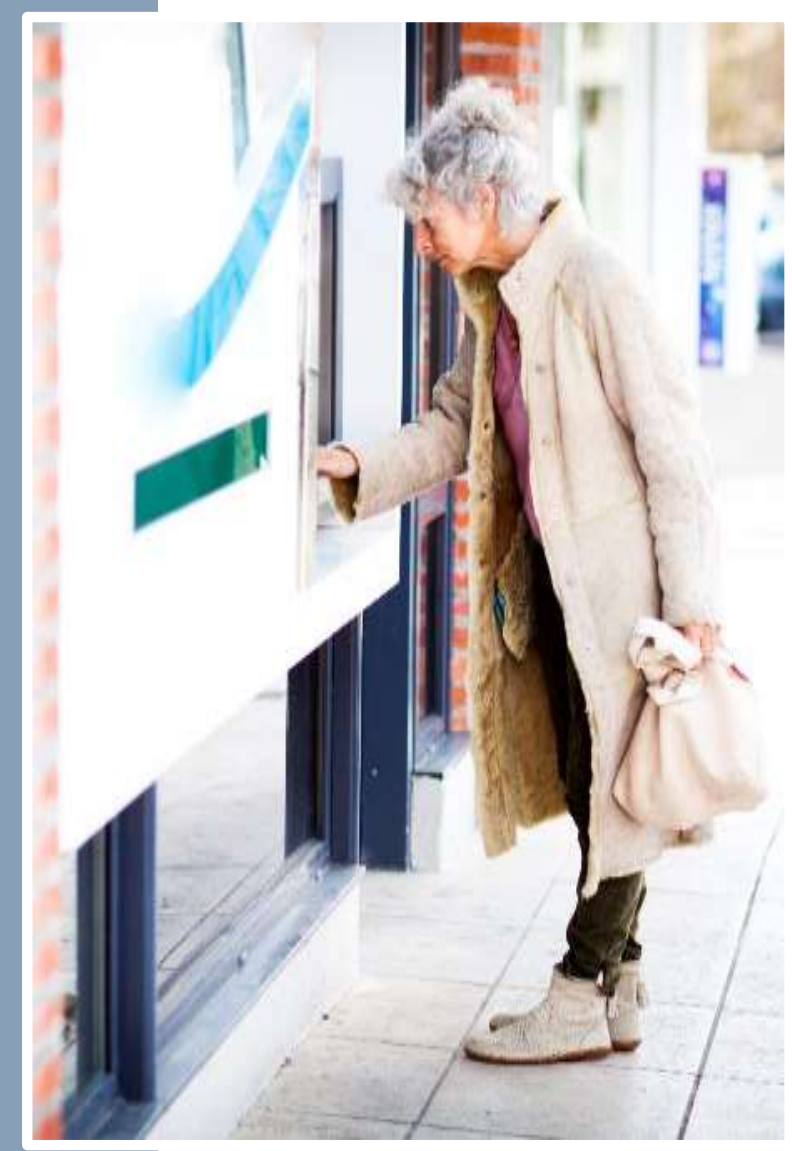

FRA19. In the last 12 months, have you or a loved one been a victim of a scam or fraud? $(n=379)$

\section{FRAUD}

Nearly two in ten (19\%) Virginia residents age $45+$ have been the victim of a scam or fraud in the past year (or know a loved one who has).

\section{Victim of a Scam or Fraud in the Past 12 Months}

Yes, I have been a victim

$13 \%$

Yes, a loved one has been a victim
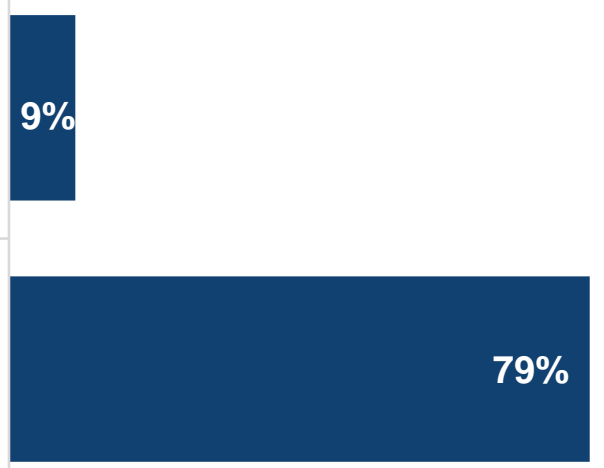

Don't know 


\section{ECONOMIC ISSUES}

Virginia residents age $45+$ have been affected by a variety of economic issues in the past 12 months.

\section{Economic Issues}

Found it more difficult to pay for essential items Made changes to your home so you could live there longer

Found it more difficult to pay for utilities

Postponed plans to retire

Postponed paying some bills

Stopped putting money into a 401 (k), IRA, or other retirement account

Found it more difficult to pay your credit cards

Found it more difficult to pay your mortgage or rent

Prematurely withdrew funds from your investments

Started a new job

Found it more difficult to pay for education expenses

Lost your job

Moved to a smaller house or apartment

Bought a new house
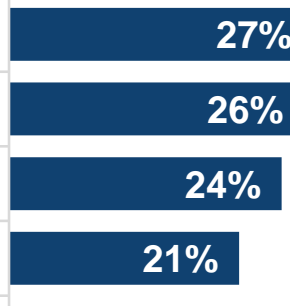

$24 \%$

$20 \%$

$19 \%$

$18 \%$

$15 \%$

$11 \%$

$10 \%$

$9 \%$

$8 \%$

$4 \%$

$2 \%$

ECON2. In the past 12 months, that is since November 2020 until now, have you [ITEM]? (Percent 'yes') (n=varies) 


\section{Survey Results for}

VirginiaSelf Questions

Issues That Impact Virginia Adults Age 45 and Older

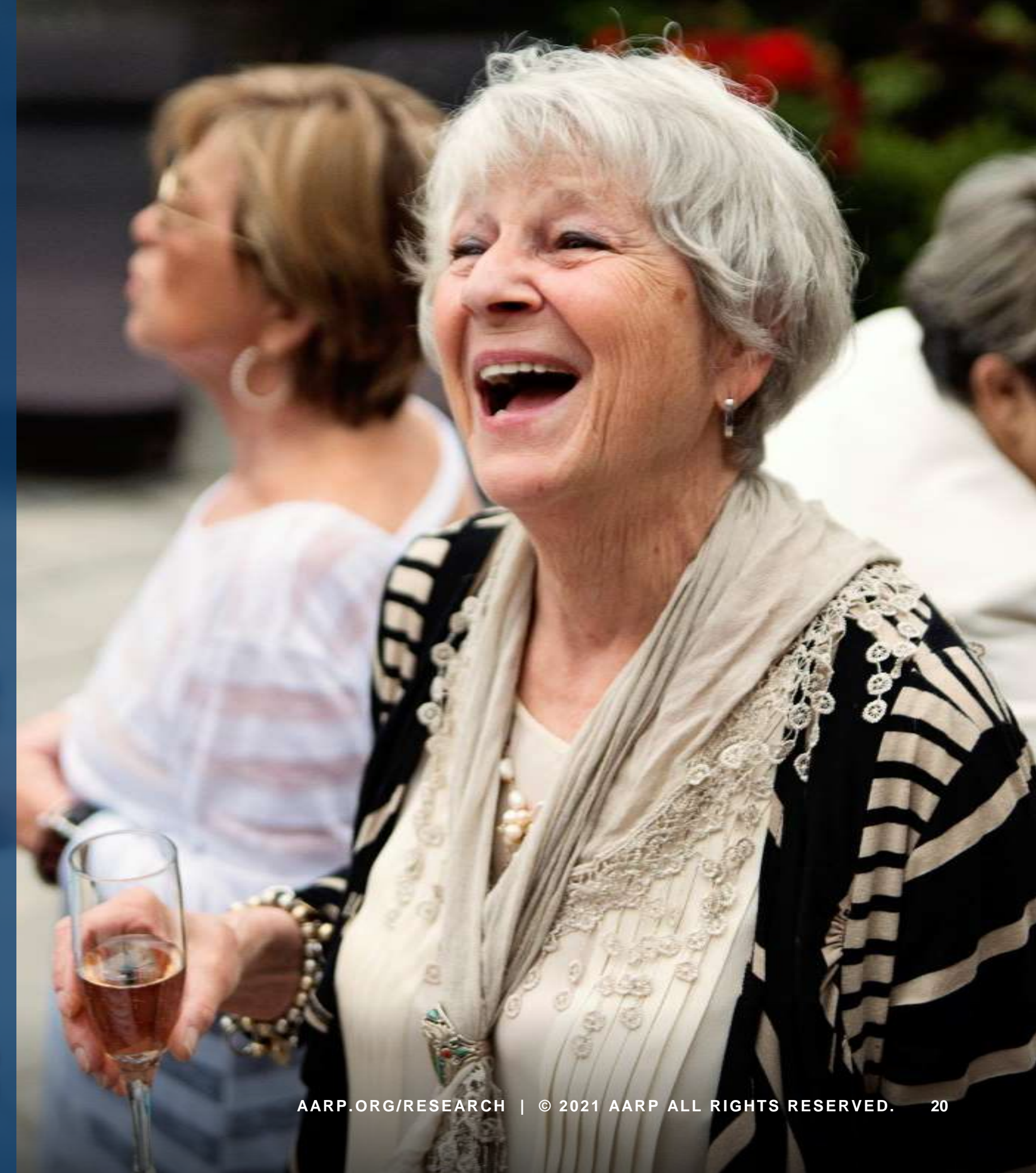




\section{ISSUES OF IMPORTANCE}

\section{Caring for a loved one is extremely or very important to a majority (84\%) of Virginia residents age $45+$.}

\section{Important Independent Living Issues}

Caring for a loved one

Getting to the places you need to go independently

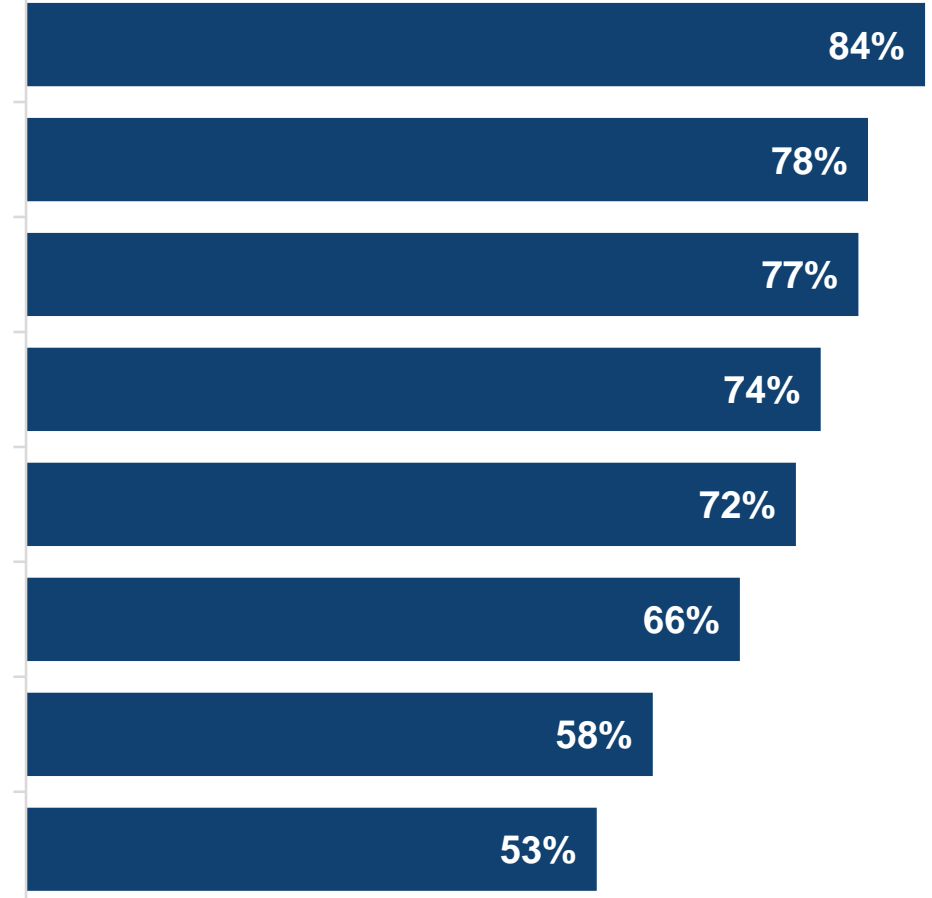

Having access to transportation if you are unable to drive

Having high quality long-term care in your community

Living in a community that meets your needs as you get older

Being connected with others in your community and having opportunities to socialize as you age 


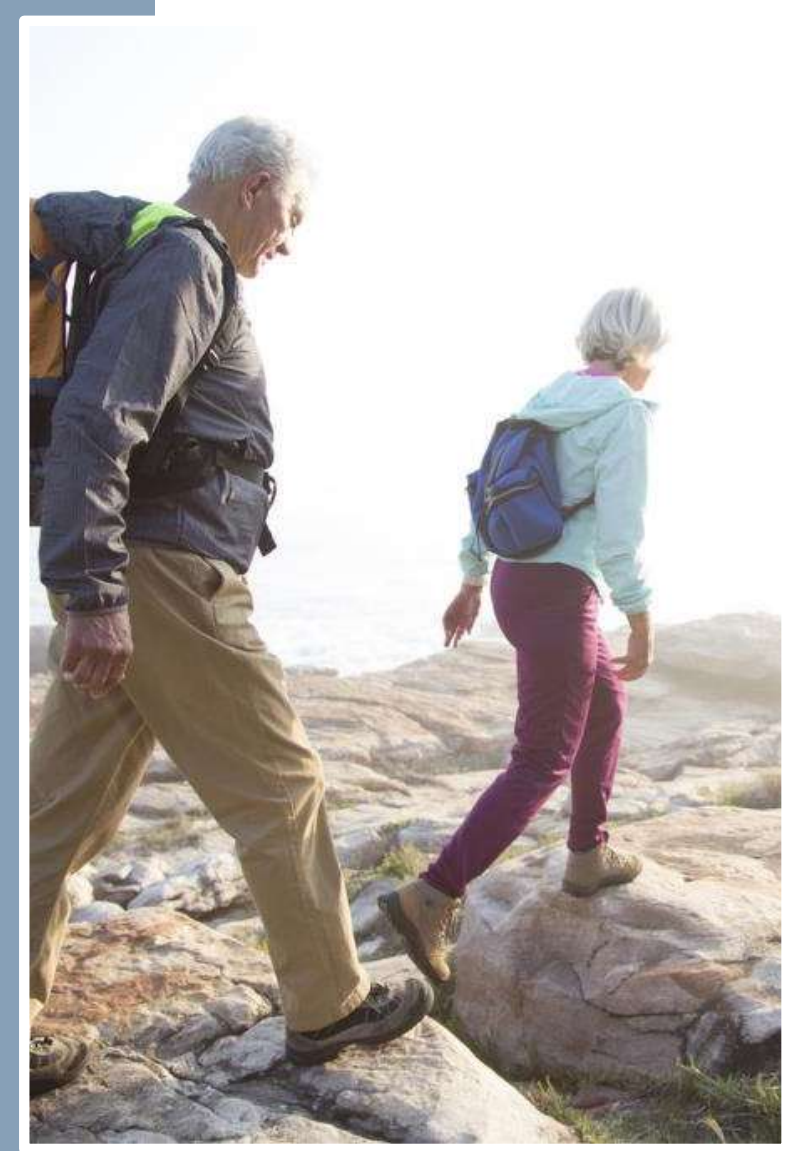

FP19. People do different things for mental sharpness. As part of your regular routine, do you [ITEM]? (Percent 'yes') $(n=379)$

\section{MENTAL SHARPNESS}

Virginia residents age 45+ have many routine behaviors for mental sharpness, including engaging in mentally stimulating activities.

\section{Routine Behaviors for Mental Sharpness}

Engage in mentally stimulating activities

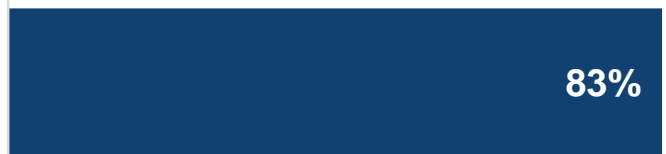

Eat nutritious and well-balanced meals

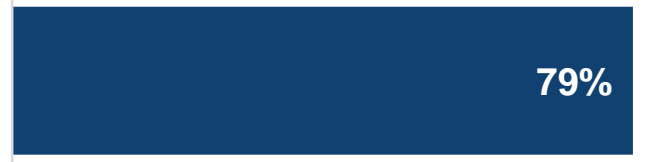

Manage stress effectively

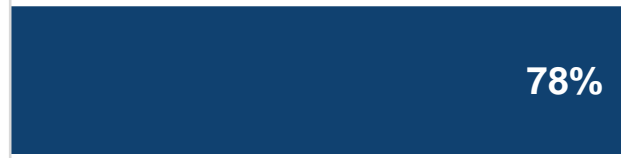

Exercise

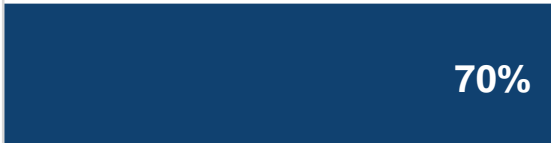

$70 \%$

Get enough restful sleep 


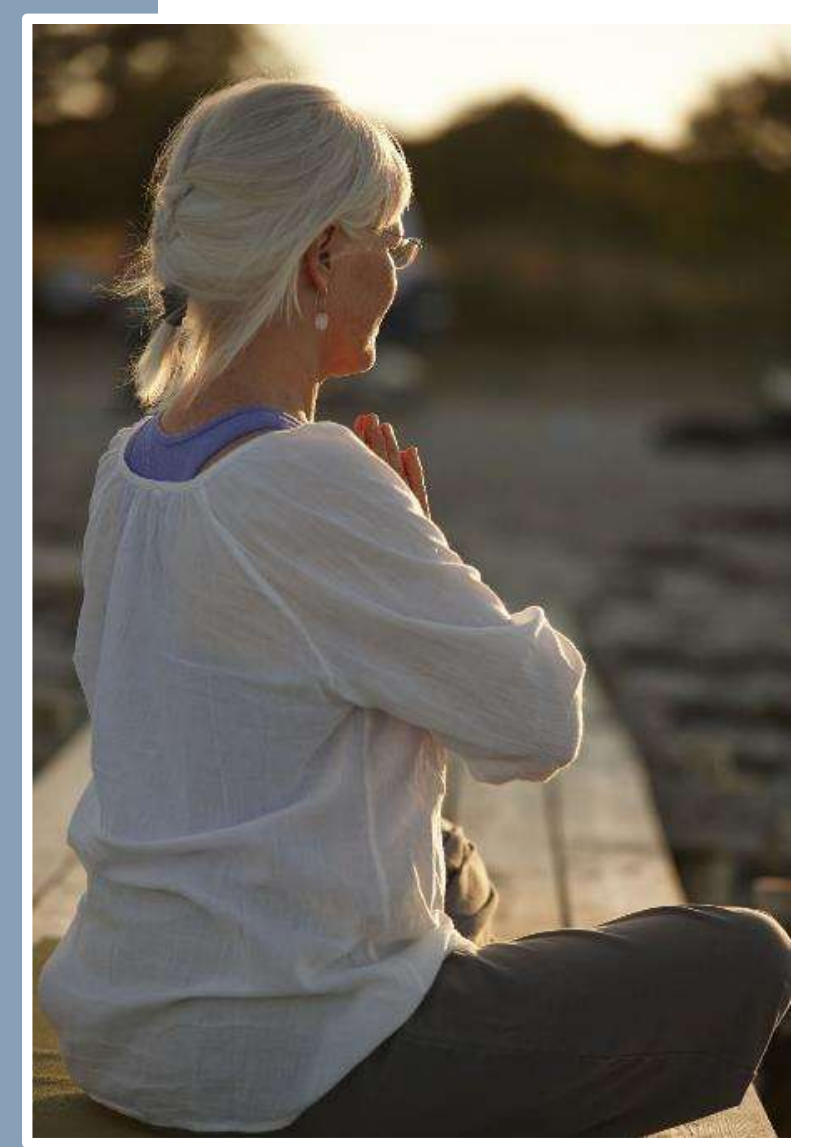

FP20. Do you think that you have more problems with memory than others your age? $(n=379)$

\section{MENTAL SHARPNESS}

Nine percent $(9 \%)$ of Virginia residents age $45+$ feel that they have more problems with memory than others their age.

More Problems With Memory Than Peers

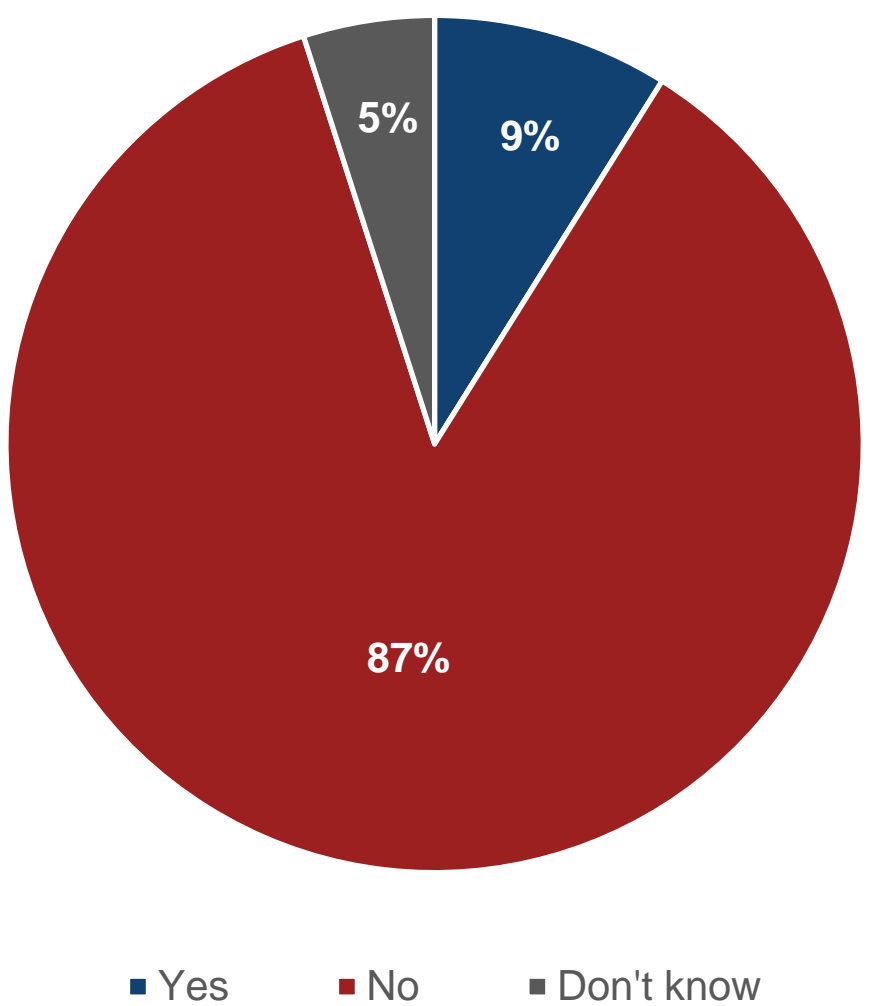




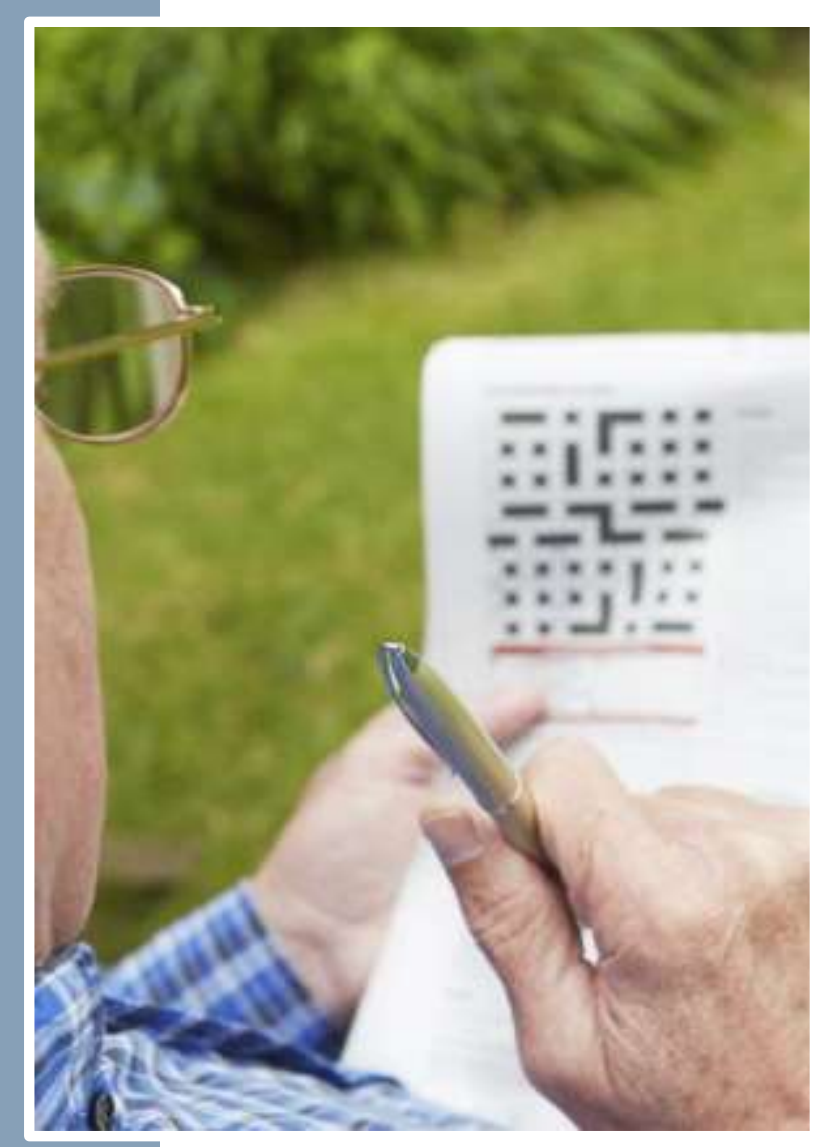

ISO9. How is your brain health or mental sharpness at this point in time? $(n=379)$

\section{MENTAL SHARPNESS}

Two-thirds $(70 \%)$ of Virginia residents age $45+$ feel that they have excellent or very good brain health and mental sharpness.

Brain Health and Mental Sharpness

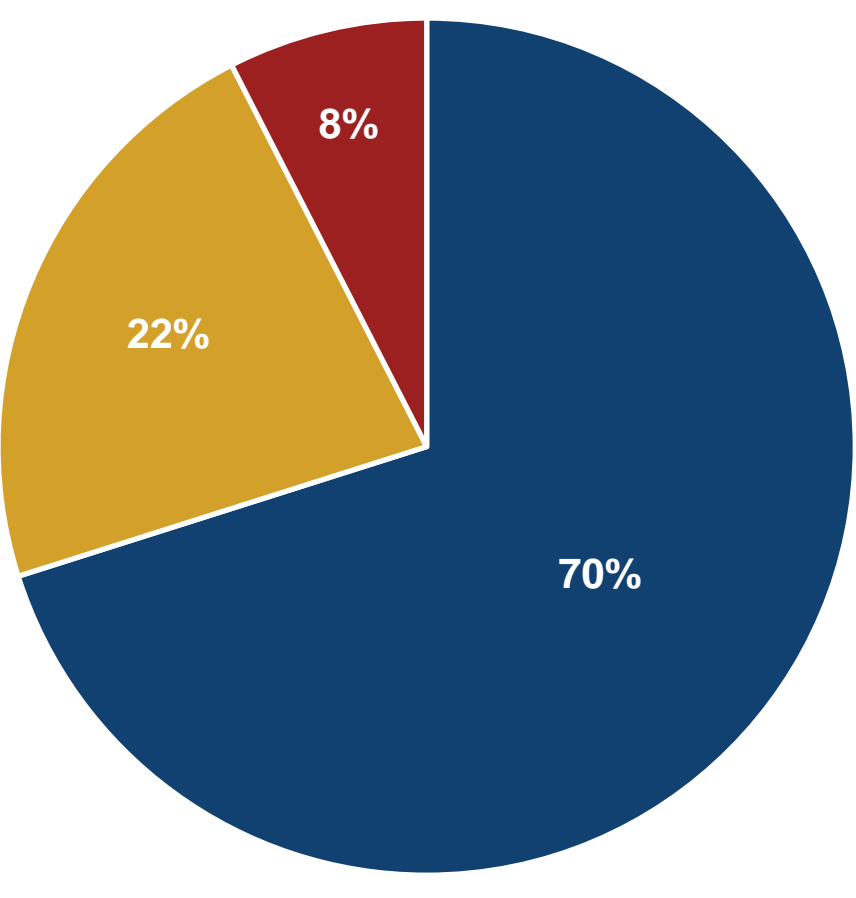

- Excellent/ very good - Good - Fair/ poor 


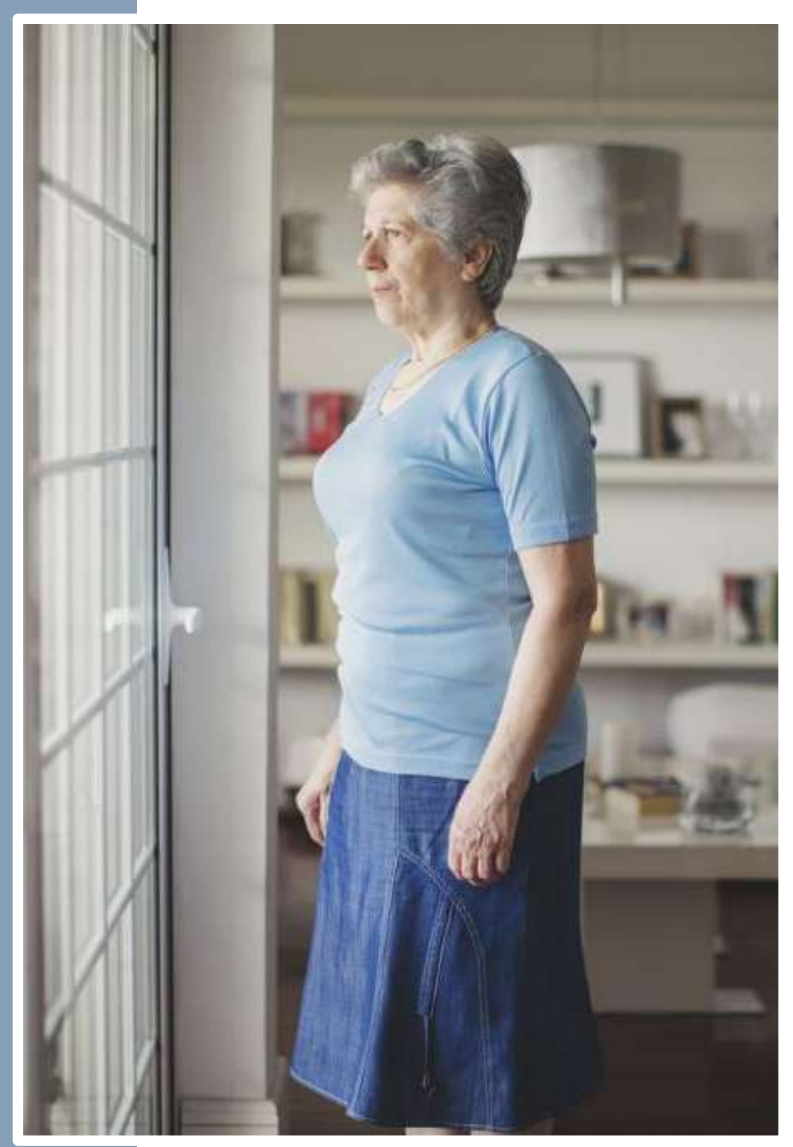

ISO2. How often do you feel the following? (Percent 'very often' or 'often') ( $n=379)$

\section{ISOLATION}

Virginia residents age 45+ feel isolated in a variety of ways, including lacking companionship and feeling left out.

\section{Frequency of Feelings of Isolation}

Feeling isolated from others

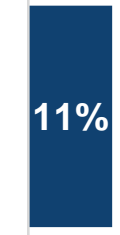

Feeling left out

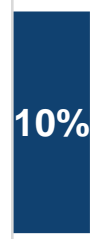




\section{TOPICS OF INTEREST}

Virginia residents age 45+ would be interested in attending events or workshops on a variety of topics, including learning and staying mentally sharp (53\%).

\section{Topics of Interest}

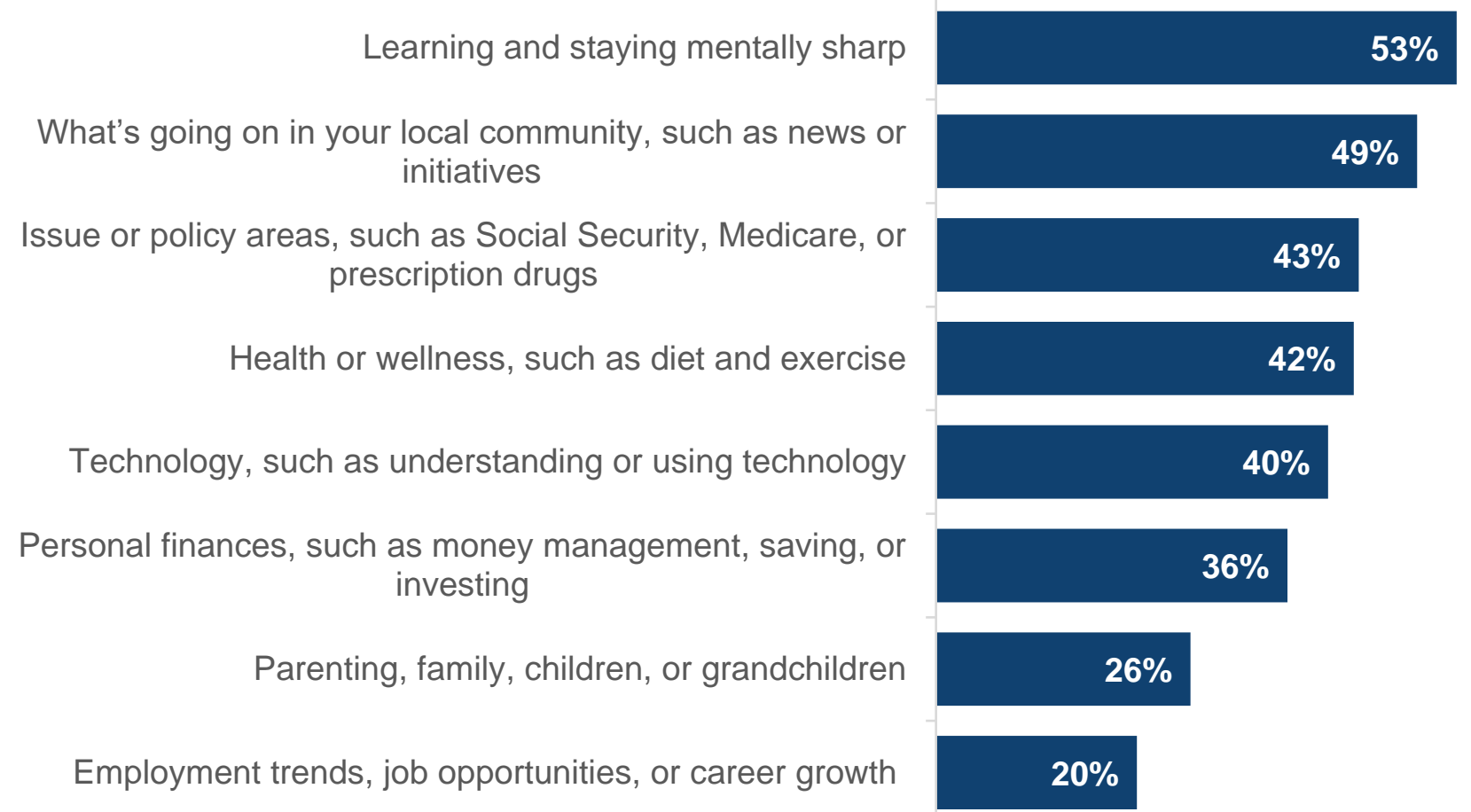

ISO51. Different people have different passions in life, or topics that interest them. How about you? Would you be interested in attending events or workshops on the following? (Percent 'yes') ( $n=379)$ 


\section{METHODOLOGY}

In November 2021, AARP engaged ANR Market Research Consultants to conduct a quantitative research study among Virginia residents age 45 and older. Topics included healthcare, the economy, financial issues, independent living, long-term care, caregiving, and retirement issues.

\section{Interviews}

\section{Virginia Adults Age 45+}

\section{Fielded in November-December 2021}

ANR completed a total of 395 interviews (132 via landline telephone, 203 via cell phone, and 60 online). Respondents were screened to meet the following criteria:

- Age 45+

- Resident of Virginia

Survey length averaged 21.5 minutes by telephone and 19.0 minutes online.

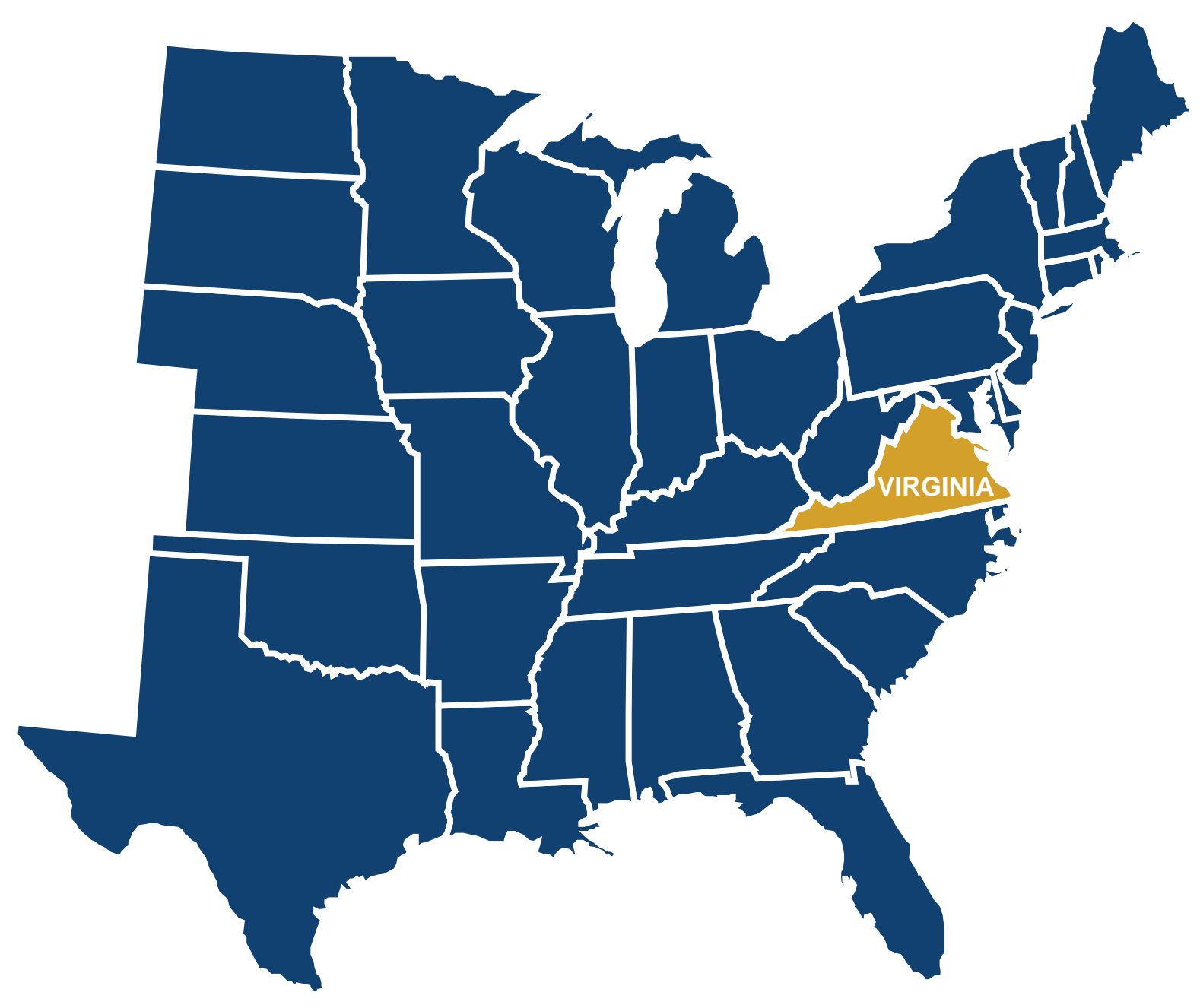




\section{METHODOLOGY}

\section{Sampling Procedure}

Landline, cell phone, and online sampling were used for this research, with the telephone sample drawn randomly from a list of Virginia residents age 18 and older, purchased from Aristotle, and online sample provided by Fulcrum. A total of 57,339 records were utilized. The list of 6,596,033 Virginia residents age 18 and older was randomly divided into 6,597 replicates of 1,000 records for telephone dialing. Initially, 20 replicates were released for calling, with additional replicates being opened as necessary. In all, 51 replicates representing a total of 50,801 records were dialed to complete the telephone portion of this study.

The sample of 395 respondents age 45 and older yields a maximum statistical error of $\pm 4.9 \%$ at the $95 \%$ level of confidence. (This means that in 95 out of 100 samples of this size, the results obtained in the sample would be within \pm 4.9 percentage points of the results obtained had everyone in the population been interviewed.)

\section{Interview Methodology}

The survey was launched on November 29, 2021 and closed on December 6, 2021.

Telephone interviewing was active between 5:30 p.m. and 9:00 p.m., with some additional calling done between 10:00 a.m. and 4:00 p.m. If necessary, up to 8 call attempts per telephone number were made to reach an eligible respondent. All numbers were called at multiple times of the day as well as days of the week to maximize each resident's opportunity for inclusion in the study.

Percentages of some questions may exceed $100 \%$ due to rounding or the use of multiple response question formats.

All data have been weighted by age, gender, and race/ethnicity according to 2019 U.S. Census Bureau Current Population Survey (CPS) statistics.

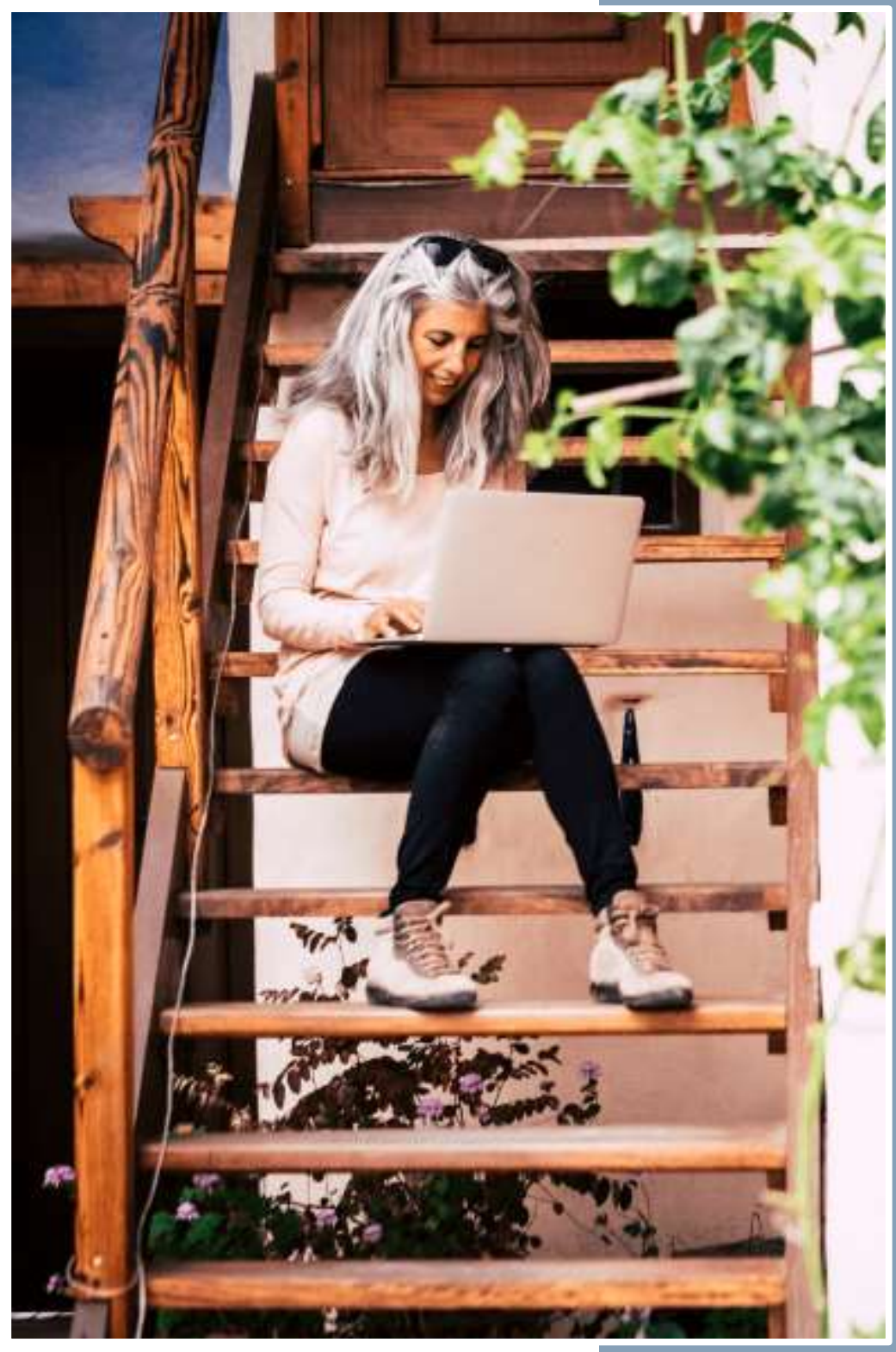




\section{ABOUT AARP}

AARP is the nation's largest nonprofit, nonpartisan organization dedicated to empowering Americans 50 and older to choose how they live as they age. With nearly 38 million members and offices in every state, the District of Columbia, Puerto Rico, and the U.S.

Virgin Islands, AARP works to strengthen communities and advocate for what matters most to families with a focus on health security, financial stability and personal fulfillment. AARP also works for individuals in the marketplace by sparking new solutions and allowing carefully chosen, high-quality products and services to carry the AARP name. As a trusted source for news and information, AARP produces the nation's largest circulation publications, AARP The Magazine and AARP Bulletin. To learn more, visit www.aarp.org or follow @AARP and @AARPadvocates on social media.

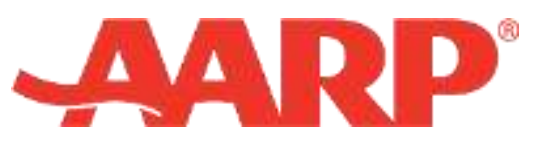

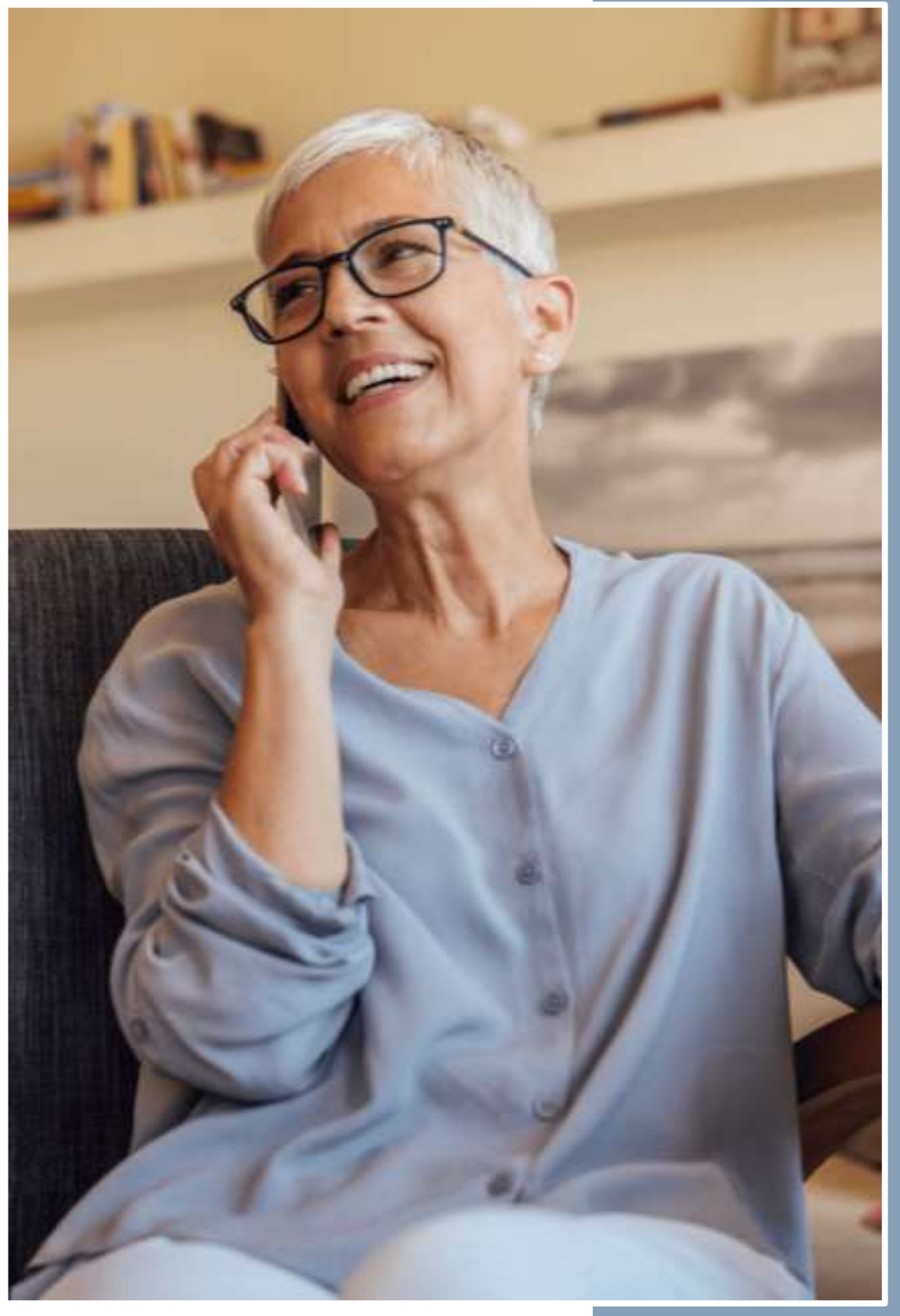

29 


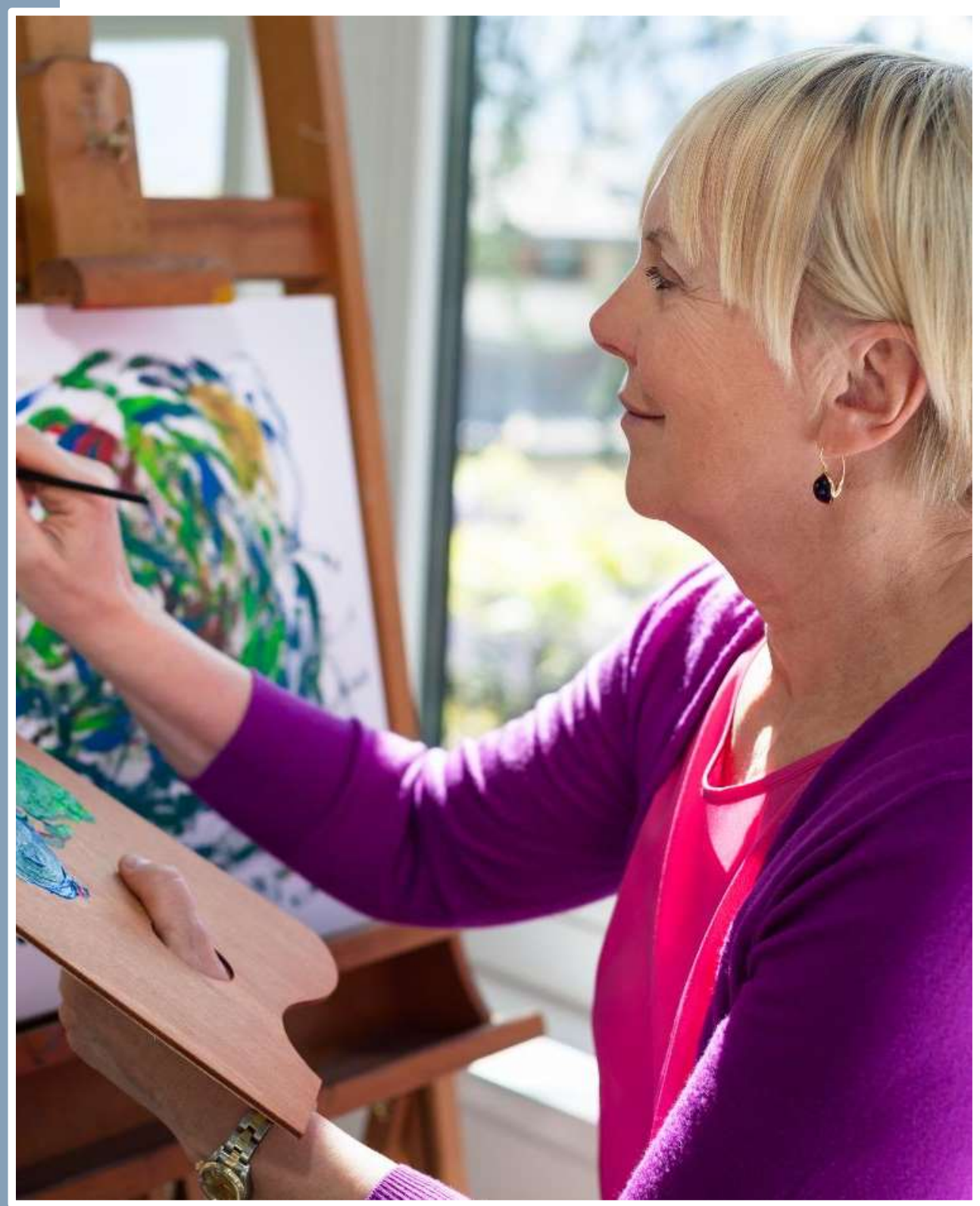

AARP

\section{CONTACT}

Cassandra Cantave,

CCantave@aarp.org

For media inquiries, please

contact media@aarp.org.

This research was designed and executed by AARP Research. 